\title{
30. WATER CONTENT VARIATIONS IN LOWER TRENCH SLOPE SEDIMENT OF VANUATU, NANKAI TROUGH, AND BARBADOS RIDGE: COMPARISON OF RESULTS FROM ODP LEGS 110, 131, AND 134 ${ }^{1}$
}

\author{
Maria V.S. Ask ${ }^{2}$ and John N. Leonard ${ }^{3}$
}

\begin{abstract}
Water content measurements from nine ODP sites in nine accretionary prisms were statistically compared to examine relationships between subduction-related dewatering and lithology, grain size, and consolidation. Varied water content profiles from Legs 134,131 , and 110 confirm the apparent inverse relationship between higher convergent rates and smaller water content values in prism sediment. Thrust zones and décollements are generally associated with large offsets of water content values. The lithology of the accreting sediment and morphology of the subducting plate are also principal factors affecting water content trends and magnitude. Calcareous sediment generally retains more water with depth than noncalcareous sediment. The highest water content values were measured at Barbados Ridge, a prism with a fairly uniform calcareous mud component with depth. The lowest water content values were measured at Vanuatu, an area where the twin submarine ridges of the d'Entrecasteaux Zone collide with the New Hebrides Island Arc and complicate subduction in the central New Hebrides Trench. Values of water content in the sediment of the Nankai Trough were of intermediate order.
\end{abstract}

\section{INTRODUCTION}

This paper compares results of water content measurements from the lower trench slope of three accretionary prisms and décollements drilled during Ocean Drilling Program (ODP) Leg 134 (Fig. 1). Westbrook et al. (1982), Bray and Karig (1985), and Moran et al. (1993) have studied how the porosity varies in accreted sediment, whereas we attempt to compare water content evolution in accreted sediment. The general water content and porosity trends are similar with depth, although their magnitudes differ. The factors that influence the porosity and water content include overburden pressure (e.g., amount of consolidation), temperature, and time (geologic age). Furthermore, parameters such as lithology, grain size, depositional history, physico-chemical factors (e.g., amount of cement), and tectonic stress contribute to the resulting sediment dewatering (Chilingarian and Rieke, 1974). Temperature, depositional history, and physico-chemical factors were not measured on our samples and will thus not be discussed. The downhole trend of water content in normally deposited marine sediment (i.e., sediment only affected by loading from sedimentation) is characterized by rapid dewatering in the upper part of the section. After initial rapid dewatering and consolidation, water content decreases very little with depth. The downhole trend of water content reveals the stress history: a continuous water content gradient indicates that the sediment has been deposited during one prevailing stress regime, whereas a discontinuous water content gradient shows that the stress history has changed during deposition.

In accretionary prisms, water content decreases faster with depth (Westbrook et al., 1982) than in undeformed sediment. This additional dewatering is due to processes related to the converging plates. Bray and Karig (1985) and Carson and Berglund (1986) studied the factors that govern the additional dewatering. Their results will be compared with the water content measurements obtained from ODP Legs 134, 131 , and 110 . We present additional data and interpretation that assists

${ }^{1}$ Greene, H.G., Collot, J.-Y., Stokking, L.B., et al., 1994. Proc. ODP, Sci. Results, 134: College Station, TX (Ocean Drilling Program).

${ }^{2}$ Luleå University of Technology, Division of Rock Mechanics/Economic Geology, S-951 87, Luleâ, Sweden. (Present address: Engineering Geology, Royal Institute of Technology, S-100 44 Stockholm, Sweden.)

${ }^{3}$ Texas A\&M University, Department of Oceanography, College Station, TX 778433146, U.S.A. (Present address: Hazen and Sawyer, Environmental Engineers \& Scientists, 4011 West Chase Blvd., Raleigh, NC 27607, U.S.A.)

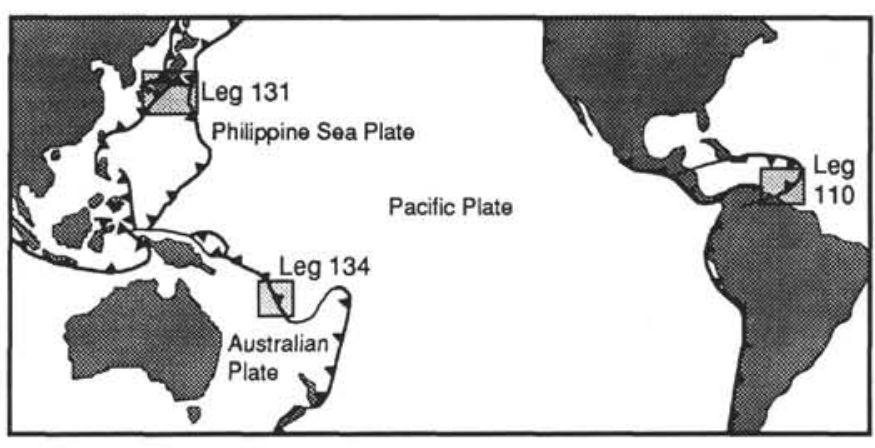

Figure 1. Map showing the location of ODP Legs 134 (Vanuatu), 131 (Nankai Trough), and 110 (Barbados Ridge) drill sites.

in delineating water content variations with respect to overburden pressure, time, lithology, grain size, and tectonic stress.

\section{GEOLOGICAL SETTING}

\section{Leg 134, Vanuatu}

Leg 134 was drilled in the collision zone between the central part of the New Hebrides Island Arc and the d'Entrecasteaux Zone (DEZ; Fig. 2A). The DEZ is composed of two morphologically distinct northern and southern parts: the continuous Northern d'Entrecasteaux Ridge (NDR) and the discontinuous Southern d'Entrecasteaux Chain (SDC; see Greene et al., this volume). The DEZ is located on the Australia-India Plate, which is obliquely subducted under the Pacific Plate at an absolute rate of $13 \mathrm{~cm} / \mathrm{yr}$ (Taylor et al., this volume) and migrates northward along the arc at $3-4 \mathrm{~cm} / \mathrm{yr}$ (Taylor et al., this volume; Greene et al., this volume). Mountainous islands of volcanic composition (Espiritu Santo and Malakula; Collot and Fisher, 1992) have risen next to the trench. These islands, together with the position of the eastern termination of the DEZ, constrain the width of the accretionary prism to about $22 \mathrm{~km}$.

The NDR is composed of mid-ocean-ridge basalt (MORB) and is overlain by layered sedimentary rocks; the SDC is a chain of seamounts and guyots with andesitic bedrocks. Bougainville Guyot is the eastern end member of the SDC and is presently being subducted. It is composed of volcanic breccia covered by $700 \mathrm{~m}$ of carbonate 


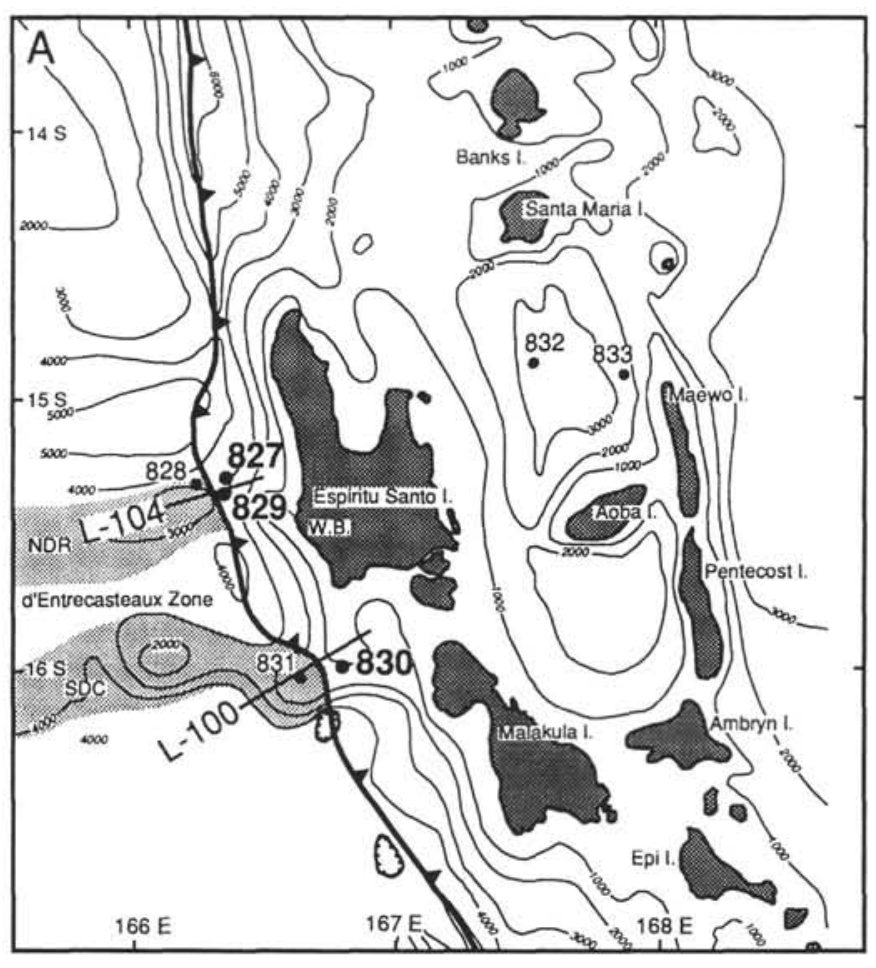

Figure 2. A. Leg 134 sites. See Figure 1 for location. Bold lines indicate cross sections shown in Figures $2 \mathrm{~B}$ and $2 \mathrm{C}$. NDR = Northern d'Entrecasteaux Ridge; SDC $=$ Southern d'Entrecasteaux Chain. Bathymetric contours are shown in meters. B. Part of multichannel seismic (MCS) line 104 (USGS, L5-84-SP), which crosses the arc slope near Sites 827 and 829. C. Part of migrated multichannel seismic reflection section (USGS line 100), which crosses the Bougainville Guyot collision zone near Site 830.

rocks and lagoonal deposits. Seismic lines (Figs. 2B and C) show that the NDR and SDC cause different styles of deformation when they impinge upon the arc. In the NDR-New Hebrides Island Arc collision zone, SeaBeam morphological data show no indentation in the arc slope but a broad, shallow protrusion (Wousi Bank) landward of the NDR (Collot and Fisher, 1991). On the other hand, the collision between the eastward-tilting Bougainville Guyot and the arc has deformed the upper slope immediately east of the guyot (Daniel et al., 1986), and a 700-m-tall north-south anticlinal dome has been formed because of this collision. Compressional forces associated with the collision of the guyot deformed and foreshortened the sedimentary and volcanic rocks of the forearc by about $10 \mathrm{~km}$. This deformation is reflected by beds dipping toward the arc and shallow eastward-dipping imbricate thrust faults (Fisher et al., 1986).

\section{Leg 131, Nankai Trough}

Leg 131 was drilled in the Nankai Trough, which is a subduction boundary between the Shikoku Basin and the southwestern Japan Arc (Fig. 3A). The Shikoku Basin is part of the Philippine Sea Plate, which is moving northwest with respect to the Eurasia Plate. Two models for calculating the relative convergence rate between the Philippine Sea and Eurasia plates have been made for the region studied by Leg 131. Seno (1977) estimated the rate at $4 \mathrm{~cm} / \mathrm{yr}$ by using seismic slip vectors, while Karig and Angevine (1986) calculated the relative convergence rate to be $2 \mathrm{~cm} / \mathrm{yr}$, based on the age of the trench wedge. The Nankai accretionary prism is about $70 \mathrm{~km}$ wide in the area studied during Leg 131 (Fig. 3 of Shipboard Scientific Party, 1991a). Most of the basement rocks of the southwest Japan Arc are composed of ancient accretionary prisms (Taira et al., 1989) that are both intruded by, and covered by, igneous rocks.
Shikoku Basin was formed (Chamot-Rooke et al., 1987) during the late Oligocene to middle Miocene as a backarc basin behind the Izu-Bonin Arc. It was formed primarily east-west spreading and possibly to a late-phase northeast-southwest spreading episode as well. The basement topography in the central part of the Shikoku Basin is composed of several highs (ridges and seamounts) trending northnorthwest-south-southeast. The central topographic high has been interpreted as a fossil spreading center that is now being subducted in the central part of the Nankai Trough, about $50 \mathrm{~km}$ west from the area of Leg 131 drilling (Fig. 3A). The shallowness of the trough, which is $\leq 4900 \mathrm{~m}$ below sea level (mbsl), can be attributed to the young age (Oligocene-Miocene) of the Shikoku Basin and the thick sediment pile in the trough. Deep Sea Drilling Project (DSDP) Leg 87 drilling showed that the sediment column is composed of two sequences: an upper turbidite layer and a lower hemipelagic layer (Kagami, Karig, Coulbourn, et al., 1986).

Seismic line NT62-8 (Fig. 3B) shows the toe of the Nankai accretionary prism. In the protothrust zone ( $\approx 2.5 \mathrm{~km}$ wide), the ocean floor is flat, whereas it is undulating and slightly higher $(\approx 200 \mathrm{~m}$ elevation) in the thrust zones (frontal thrust to third thrust; Fig. 3B).

\section{Leg 110, Barbados Ridge}

Leg 110 drilled in the Barbados Ridge accretionary prism. Barbados Ridge is located east of the Lesser Antilles Island Arc $(\approx 160 \mathrm{~km})$ and forms the leading edge of the Caribbean Plate (Fig. 4A), where the Atlantic oceanic crust is being subducted toward the west beneath the Antilles. In the Leg 110 area, several models for plate convergence have been established. The most probable model suggests a relative motion of $2 \mathrm{~cm} / \mathrm{yr}$ (Stein et al., 1988). Faster convergence rates, 3 to 4 $\mathrm{cm} / \mathrm{yr}$, have been suggested by Sykes et al. (1982), and slower convergence rates, $0.25-0.50 \mathrm{~cm} / \mathrm{yr}$, have been calculated from seismic slip rates by Dorel (1981) and by Molnar and Sykes (1969).

Leg 110 extended across the northwestern flank of the Tiburon Rise. The accretionary prism is about $150 \mathrm{~km}$ wide in this area. The present position of the east-northeast-trending Tiburon Rise ponds northward-flowing Orinoco fan turbidites (Wright, 1984). Consequently, few terrigenous turbidites occur in the current abyssal section north of the rise. Pelagic and hemipelagic sediment has formed a clay-dominated prism.

Figure 4B shows the toe of the Barbados Ridge accretionary prism. There is a smooth transition between the undeformed and accreted sediment on the seafloor (at shotpoints 200-400), except at the second thrust (at about shotpoint 340).

\section{METHODS}

The laboratory procedures for water content measurements during Legs 134, 131, and 110 followed those outlined by Boyce (1976). These procedures are outlined in the "Physical Properties" sections of the "Explanatory Notes" chapters of the Initial Reports for the respective legs (Collot, Greene, Stokking, et al., 1992; Taira, Hill, Firth, et al., 1991; Mascle, Moore, et al., 1988). For calculation of the water content as a percent of the dry mass, the mass of both wet- and dry-samples is measured. The water content is calculated according to the formula:

$$
\text { Water content }=\frac{M_{t}-M_{d}}{M_{d}-r \times M_{t}} \times 100
$$

where $M_{t}=$ total (wet) mass of sample (g), $M_{d}=$ dry mass of sample $(\mathrm{g})$, and $r=$ salinity $(\%)$. As the water content is the ratio between the mass of the fluid $\left(M_{t}-M_{d}\right)$ and the mass of the grains $\left(M_{d}-r \times M_{t}\right)$, water content can be greater than $100 \%$. The measurements are made by using a programmed dual pan system with an estimated error of $\pm 0.03 \mathrm{~g}$. Samples were dried in an oven at $110^{\circ} \pm 5^{\circ}$ for $24 \mathrm{hr}$ as prescribed by ASTM. All water content values are corrected for salt, assuming a pore-water salinity of $35 \%$. The routine analytic precision 

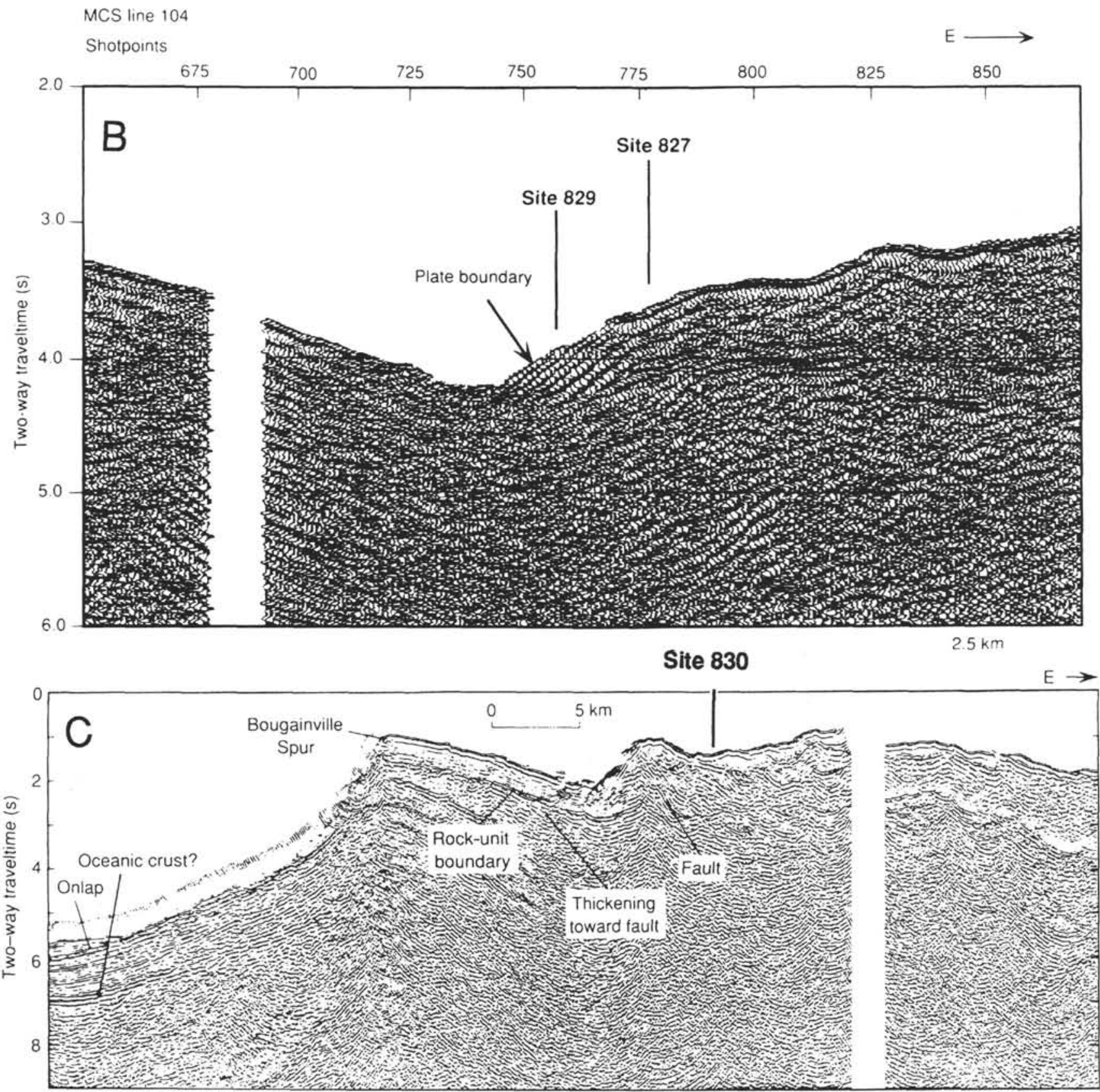

Figure 2 (continued).

depends on the sample mass and the actual pore-water salinity but is less than $\pm 1 \%$ for all samples.

We used core description forms and core photos from the respective legs to determine the lithology of each sample. For Leg 131, the sample lithologies were entered for all measurements. Table 1 summarizes the lithologies, grain sizes, and composition, which are incorporated in the following sections. The term mud is used for both silt and clay, because exact lithologic descriptions and grain-size analyses for individual physical properties samples could not be made. Although this causes some uncertainty in interpretation, particularly in heterogeneous core intervals, our method of defining different sediment types directly from core description forms and core photos was the most accurate method available. Statistical analyses of the water content data were performed using the General Linear Model procedure in the Statistical Analyses System environment (see "Statistical Results," this chapter).

\section{DRILLING RESULTS}

\section{Vanuatu, Leg 134 Sites}

Drilling at two closely spaced sites (Sites 827 and 829) within 4 $\mathrm{km}$ east of the seafloor trace of the subduction zone penetrated the accretionary prism where the NDR is colliding with the arc (Figs. 2A and B). Site 827 is located on a small terrace and Site 829 is located on the slope. Drilling at these sites penetrated silt, sand, and breccia with typical fold-thrust geometry. Site 830 is located high on the upper forearc slope about $7 \mathrm{~km}$ east of the trace of the subduction zone between the SDC and the central New Hebrides Island Arc (Fig. 2C). Coarse clastic sediment (silt and sand) and one shallow thrust fault were penetrated. The complete lithostratigraphy, structural geology, and physical properties results are outlined in the site report chapters for the respective sites (Collot, Greene, Stokking, et al., 1992). 

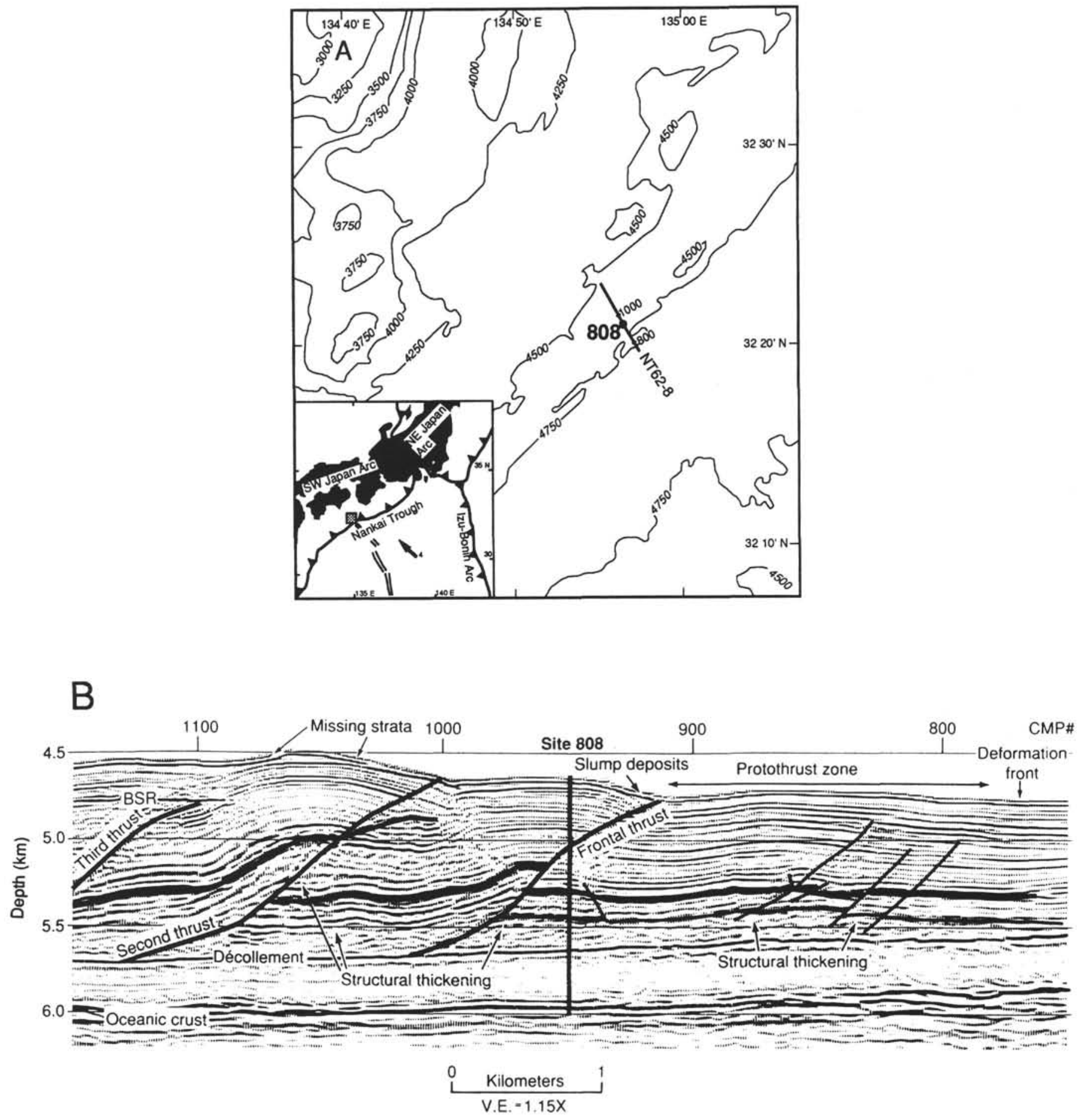

Figure 3. A. Leg 131, Site 808. See Figure 1 for location. Bold line indicates part of seismic line NT62-8 shown in Figure 3B. Bathymetric contours are shown in meters. B. Depth section generated from seismic line NT62-8 and drilling results. From an interpretation by Moore et al. (1991). 

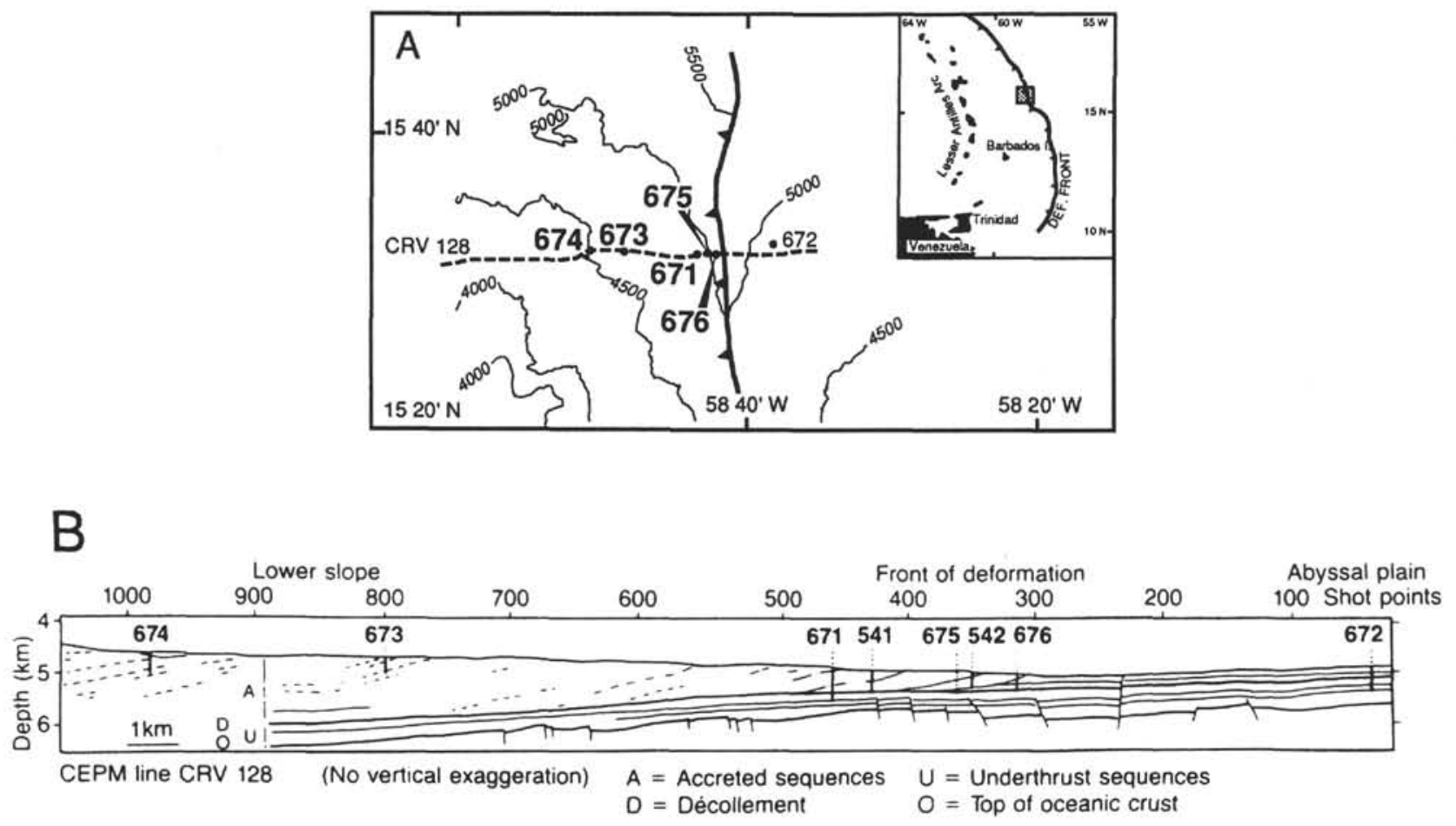

Figure 4. A. Leg 110 sites. See Figure 1 for location. Bold dashed line indicates seismic line CRV 128, shown in Figure 4B. DEF. FRONT = deformation front. Bathymetric contours are shown in meters. B. Line drawing of depth section generated from seismic line CRV 128 and drilling results, located as indicated in Figure 4A. Digitized from interpretation of CRV 128 by Shipboard Scientific Party (1988).

\section{Sites 827, 829: NDR Collision Sites}

The water content variation with depth at Site 827 shows the effect of collision, but not to the extent seen at the deeper levels of Site 829. In spite of differences in lithologic composition, water content trends at Sites 827 and 829 show a remarkable similarity.

\section{Drilling Results from Site 827}

Tectonic deformation was small or absent in the top interval from 0 to 141 meters below seafloor (mbsf; Fig. 5), which is composed mainly of volcanic silt. Water content changes little with depth, and vary generally from $48 \%$ to $35 \%$. At 107 mbsf, sediment becomes lithified, and tectonic deformation begins to be expressed as smallscale faults that correspond to a small increase of about $+5 \%$ in the water content value. Farther down, between 141 and 252 mbsf, structural features such as scaly fabric and shear zones become common with small faults. This interval is interpreted to be accreted trench fill, and is mostly composed of calcareous volcanic siltstone (Reid et al., this volume). Water content values from 141 to $252 \mathrm{mbsf}$ vary from $32 \%$ to $60 \%$, which is a wider range than in the volcanic silt above. Below $252 \mathrm{mbsf}$, the core recovery dropped to very low levels due to the penetration of a sed-lithic conglomerate with pebble-sized clasts of volcanic breccia (andesite and dacite), siltstone, and sandstone (Reid et al., this volume). The sequence from 252 to $400 \mathrm{mbsf}$ is interpreted to be accreted debris flows. The water content values fall into two groups: low values $(<11 \%)$ originating from the clast-dominated samples in the breccia and conglomerate, and values between $23 \%$ to $34 \%$, originating from the matrix-dominated samples.
Table 1. Summary of the different sediment types for Legs 134, 131, and 110.

\begin{tabular}{|c|c|c|}
\hline Sediment class & Principal name & Description \\
\hline \multirow[t]{4}{*}{$\begin{array}{l}\text { Siliciclastic (S) and } \\
\text { volcaniclastic (V) } \\
\text { sediments }\end{array}$} & & $\begin{array}{l}S \text { sediments are composed of }>60 \% \mathrm{~S} \text { and } \mathrm{V} \\
\text { grains, with a higher proportion of } \mathrm{S} \text { than } \mathrm{V} \text {. } \\
\mathrm{V} \text { sediments are composed of }>60 \% \mathrm{~V} \text { and } \mathrm{S} \\
\text { grains, with a higher proportion of } \mathrm{V} \text { than } \mathrm{S} \text {. }\end{array}$ \\
\hline & Mud & Grain size: mud $<0.0625 \mathrm{~mm}$ (clay + silt). \\
\hline & Sand & Grain size: $\leq 0.0625$ sand $\leq 2.00 \mathrm{~mm}$. \\
\hline & $\begin{array}{l}\text { Breccia and } \\
\text { conglomerate }\end{array}$ & $\begin{array}{l}\text { Matrix of finer grains (Ssand), clasts of coarser size } \\
\text { ( } \geq \text { sand). }\end{array}$ \\
\hline \multirow[t]{4}{*}{ Pelagic sediments } & Ooze & $\begin{array}{l}\text { Unlithified calcarcous and/or siliceous pelagic } \\
\text { sediments. }\end{array}$ \\
\hline & Chalk & $\begin{array}{l}\text { Partially lithified pelagic sediments predominantly } \\
\text { composed of calcareous pelagic grains. }\end{array}$ \\
\hline & Limestone & $\begin{array}{l}\text { Lithified pelagic sediments predominantly } \\
\text { composed of calcareous pelagic grains. }\end{array}$ \\
\hline & Carbonate & Unlithified to lithified pelagic sediments. \\
\hline \multirow[t]{2}{*}{ Mixed sediments } & Marl & $\begin{array}{l}30 \%-70 \% \text { mud and } 30 \%-70 \% \text { calcareous pelagic } \\
\text { sediments. }\end{array}$ \\
\hline & Mixed sediments & $\begin{array}{l}40 \%-60 \% \mathrm{~S} \text { and } \mathrm{V} \text { grains and } 40 \%-60 \% \text { pelagic } \\
\text { and neritic grains. }\end{array}$ \\
\hline \multirow[t]{2}{*}{ Modifiers } & $\begin{array}{l}\text { Siliceous (S) } \\
\text { Caicareous (S) } \\
\text { Volcanic (V) } \\
\text { Ashy (V) }\end{array}$ & $\begin{array}{l}10 \%-30 \% \text { of the grains are composed of the } \\
\text { respective modifier, or a mix of the modifiers. }\end{array}$ \\
\hline & Unmodified & Less than $10 \%$ of any modifier. \\
\hline
\end{tabular}

\section{Drilling Results from Site 829}

Relatively undeformed silt, siltstone, and chalk in the top interval from 0 to 171.9 mbsf (Fig. 5) commonly show a gradual downhole decrease in water content, from $48 \%$ to $34 \%$. Upper Oligocene to lower Miocene foraminiferal chalk from 60.5 to $99.4 \mathrm{mbsf}$ was poorly 


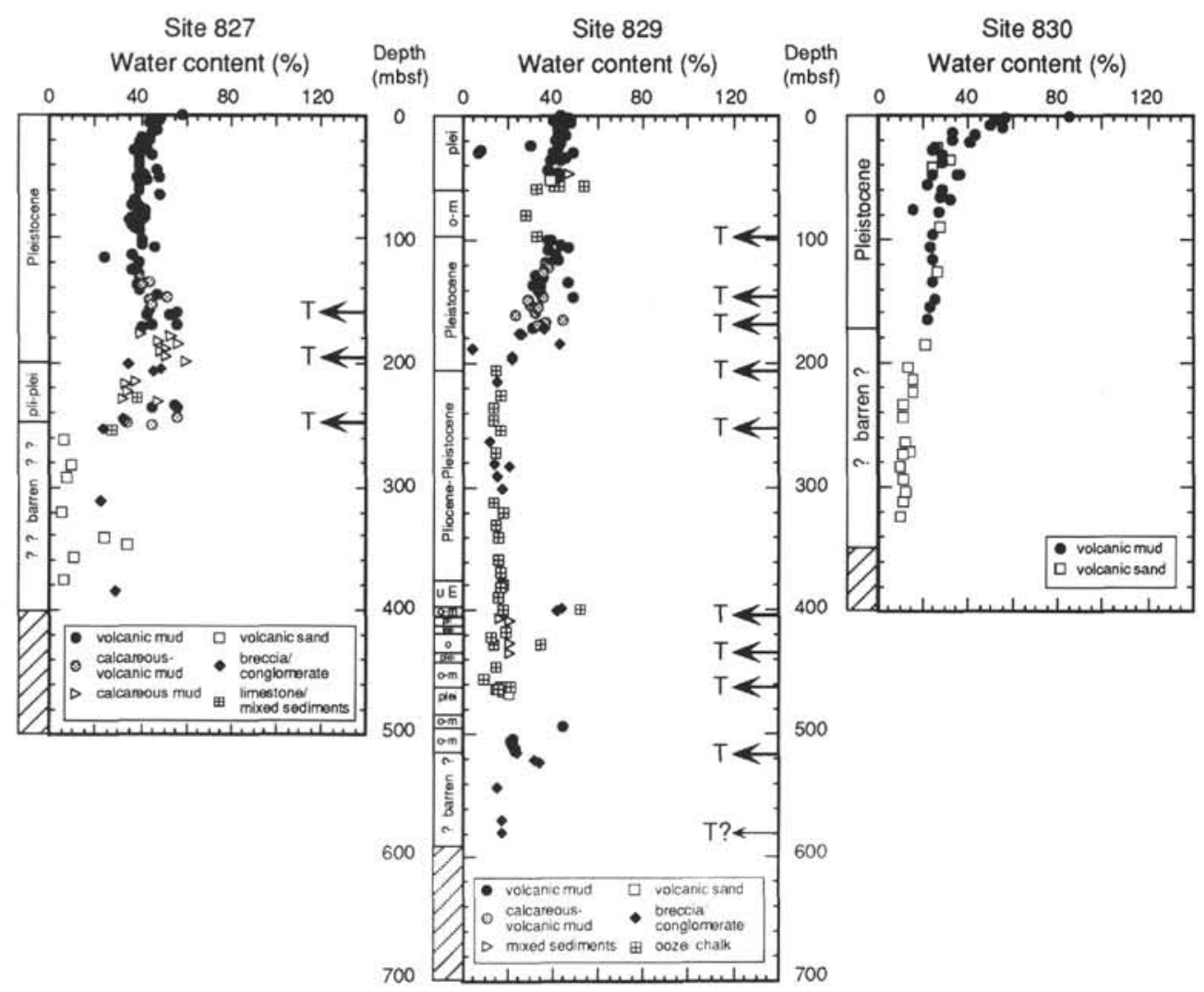

Figure 5. Water content variations vs. depth for Leg 134 sites, including biostratigraphic age, sample lithologies, and structural features. Key to symbols in age column at Site 829: plei = Pleistocene; pli = Pliocene; o-m = Oligocene to Miocene; $\mathrm{o}=$ Oligocene; $\mathrm{uE}=$ upper Eocene. Key to structure symbols: $\mathrm{T}=$ thrust plane; $\mathrm{T}$ ? = possible thrust plane.

recovered, but two measurements suggest that the chalk is much drier than the silt, with a water content of about $30 \%$. A $6 \%$ increase in water content was observed at the first thrust fault ( $99 \mathrm{mbsf})$. Sediment becomes lithified between the first and second thrust fault, at about 127 mbsf.

The interval from 171.9 to 205.2 mbsf records a transition from wet rocks above $171.9 \mathrm{mbsf}$ to rocks below $205.2 \mathrm{mbsf}$ that are dry except at thrust faults. This highly deformed zone of sedimentary tectonic melange, composed of sheared chalk-siltstone breccia, is characterized by wide-ranging values of water content $(4 \%-42 \%)$. Highly deformed and sheared chalk breccia, volcanic breccia, siltstone, sandstone, and silty chalk were recovered from 205.2 to $590.3 \mathrm{mbsf}$. These sediments and rocks generally have a very low water content $(10 \%-$ $20 \%$ ), but there is a sudden increase in water content (to $32 \%-55 \%$ ) in the thrust-fault zones, particularly in the major shear zones from 400 to 590 mbsf (Fig. 5). In these major shear zones, the $\mathrm{CaCO}_{3}$ content varies widely (Fig. 4 in Leonard and Ask, this volume).

\section{Drilling Results from Site 830: SDC Collision Site}

Lithostratigraphic interpretation suggests that the upper $174.9 \mathrm{~m}$ of Site 830 consists of mostly unlithified sandy turbidites and volcanic silts that were deposited along an unstable slope. Calcium carbonate content starts out at a low level $(<25 \%)$ at the seafloor and decreases to almost zero at 174.9 mbsf. The water content (Fig. 5) exhibits a definite downhole trend with rapid dewatering from $85 \%$ at the mud line to less than $25 \%$ water content at $49 \mathrm{mbsf}$, continuing to decrease gradually to $22 \%$ at 174.9 mbsf. There is some scatter of the water content in the unlithified sediment ( $0-97 \mathrm{mbsf})$, whereas the lithified sediment (97-350.6 mbsf) displays uniform water content. A small shift of about $5 \%$ in the water content trend at 174.9 mbsf marks a change in the lithology to a highly geochemically altered epiclastic sequence, whose components were derived from the nearby volcanic islands. These rocks have undergone intense brittle deformation from tectonic processes and show increasingly scaly fabric downhole. Water content generally decreases downhole in this sediment (Fig. 5).

\section{Nankai Trough: Leg 131}

Only one site (Site 808) was drilled during Leg 131 (Fig. 3A). Drilling penetrated the frontal region of the accretionary prism (clastic sediment deposited by turbidity currents), underplated sediment (hemipelagic sediment), and oceanic basement (Fig. 3B). The complete lithostratigraphy, structural geology, and physical properties results are outlined in the site report chapter of Taira, Hill, Firth, et al. (1991).

\section{Drilling Results from Site 808}

The top interval from 0 to 215 mbsf is composed of sediment ranging from clayey silt to sand of varying thickness, thin ash layers with bioturbation occurring in some clayey silt layers. Gravity-induced slumping is observed in the cores down to about $200 \mathrm{mbsf}$ and the lithology changes to larger mean grain sizes in the clayey siltstone and silty claystone, which is inversely related to water content. Water content varies widely from $93 \%$ to $15 \%$ but shows two distinct clusters (Fig. 6): the smaller values $(15 \%-30 \%)$ correspond to sandy turbiditic zones, whereas the larger values $(>40 \%)$ represent the fine-grained end-members of the turbidite sequence. Water content data for finegrained material delineate with little scatter show a clear downhole trend. A shift to lower water content values with less scatter occurs from 215 to $395 \mathrm{mbsf}$. The range of the water content is even less in the underlying lithified sediment (below $263 \mathrm{mbsf}$ ). Water content decreases gradually from $46 \%$ to $14 \%$ between 215 and 395 mbsf. The frontal thrust zone was intersected between 357 and 395 mbsf. 


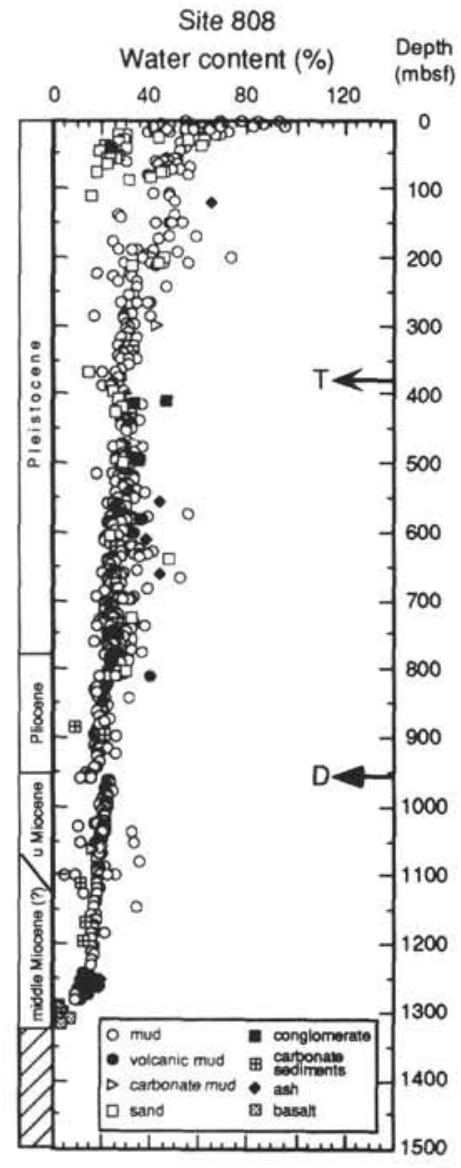

Figure 6. Water content variations vs. depth for Leg 131 Site 808, including biostratigraphic age, sample lithologies, and structural features. The term mud denotes unmodified mud. Key to structure symbols: $\mathrm{D}=$ décollement; $\mathrm{T}=$ thrust plane (i.e., the frontal thrust).

Sediments in this zone have a coarser mean grain size than overlying sediment, and water content is less than $29 \%$.

Sediment underlying the frontal thrust zone (395-812 mbsf) is mainly composed of silty claystone and clayey siltstone. The water content exhibits a small spike (by $5 \%-10 \%$ ) immediately below the frontal thrust zone (Fig. 6). Water content values between 395 and 812 mbsf are less scattered where the sediment is richer in hemipelagic components; water content values generally vary from $35 \%$ to $20 \%$. The interval from 812 to 965 mbsf is composed of thoroughly bioturbated mudstone rich in foraminifers that contains intercalated layers of tuff and vitric sandstone in the upper $12 \mathrm{~m}$ and traces of volcanic glass in the remainder ( $824-965 \mathrm{mbsf}$ ). At $812 \mathrm{mbsf}$, water content drops to about $20 \%$ and decreases downhole with very little scatter to about $17 \%$ at 946 mbsf. The water content drops to an average of $14 \%$ in the décollement, which was intersected from 950 to $965 \mathrm{mbsf}$.

An offset of water content (about $8 \%$ ) occurs below the décollement (Fig. 6). Although no change in the lithology was noted, sediment below the décollement is severely underconsolidated (i.e., the vertical stress is much bigger than any of previous in-situ stresses of the sediment; Moran et al., 1993). The water content decreases from about $22 \%$ to $15 \%$ between $965 \mathrm{mbsf}$ and $1240 \mathrm{mbsf}$, exhibiting a similar water content gradient compared to the interval between 824 and 965 mbsf. Acidic ash interbedded with mottled (thoroughly bioturbated) mudstone was recovered between 1240 and 1290 mbsf, with water content values ranging between $8 \%$ and $19 \%$. Yet another shift to lower water content values occurs in the basaltic basement (1290-1327 mbsf), where the water content is less than $7 \%$.

\section{Barbados Ridge: Leg 110 Sites}

Sites 676, 675, and 671 (Fig. 4A) are situated within $4 \mathrm{~km}$ west of the deformation front. Sites 673 and 674 are closer to the island arc, about $13 \mathrm{~km}$ and $18 \mathrm{~km}$ due west of the deformation front, respectively. Drilling penetrated similar lithologies at all sites, mainly finegrained sediment with a significant content of calcareous components (see following sections). The décollement was penetrated at Sites 676, 675 , and 671 in areas where the accretionary wedge is thin $(<500 \mathrm{~m}$; Fig. 4B). The sites are discussed below from east to west-in the order drilled - starting from the deformation front. The complete lithostratigraphy, structural geology, and physical properties results are outlined in the site report chapters for the respective sites in Mascle, Moore, et al. (1988).

\section{Sites 676, 675, 671: Deformation Front}

The water content variation with depth at Sites 676, 675, and 671 shows the effect of tectonic thickening. The water content follows a wide-ranging zigzag pattern with depth at Site 676 (250 m arcward of the deformation front), which is mimicked by a sigmoidal pattern at Site 671 (4 km west of the deformation front).

\section{Drilling Results from Site 676}

The water content (Fig. 7) shows a rapid and linear decrease from $116 \%$ to $54 \%$ through the 35 -m-thick sequence, which mainly consists of calcareous or ashy mud and clay that overlies the frontal thrust. The sliver of sediment (marl and calcareous mud) between the frontal thrust (at $35 \mathrm{mbsf}$ ) and $162.2 \mathrm{mbsf}$ is characterized by an exponentially decreasing water content trend. Two marl samples (at 141 and 144 mbsf) yielded distinctly lower water content values (about $45 \%$ ), which may reflect a discrete fault that intersected the Miocene/Pliocene transition zone (Fig. 7). Sediment from 162.2 to $262.7 \mathrm{mbsf}$ is composed of claystone and mudstone with a large scatter of water content $(52 \%-92 \%)$. A distinct spike in the water content at more than $10 \%$ was measured adjacent to the thrust zone at $205 \mathrm{mbsf}$. The water content scatter generally is narrower from 234.7 to $262.7 \mathrm{mbsf}$, where it ranges from $67 \%$ to $92 \%$. The water content drops from $103 \%$ to $64 \%$ in the décollement (271-305 mbsf; Fig. 7), which is composed of siliceous mudstone and mudstone of late Miocene age. This decreasing water content trend continues downward to sub-bottom depth (262.7-310.2 mbsf).

\section{Drilling Results from Site 675}

Besides a 0.2-m-thick core at the mud line (that we will not discuss), Site 675 was only cored from 321 to 388 mbsf. The cores are composed of barren claystone and mudstone and locally siliceous mudstone of early Miocene age. At the top of the cored interval (321-335 mbsf), the water content is constant (56-58\%; Fig. 7). A shift to a higher and more scattered water content trend $(65-83 \%)$ occurs across the deformation zone at $335 \mathrm{mbsf}$ and down to 360 mbsf. Only three samples exist in the décollement (360-378 mbsf), but they suggest a decreasing water content trend. This trend continues beneath $378 \mathrm{mbsf}$ down to sub-bottom depth ( $388 \mathrm{mbsf}$ ), where the water content is $47 \%$.

\section{Drilling Results from Site 671}

The top interval ( $0-389.6 \mathrm{mbsf})$ is composed mainly of mud and marl commonly with interbeds of ash, and becomes lithified near 120 mbsf. The water content displays an exponential decrease from $137 \%$ to $45 \%$ in the uppermost $128 \mathrm{mbsf}$, where the first major thrust fault was intersected (Fig. 7). Except for two zones with higher, and more scattered water content values (at 128-168 mbsf and 285-310 mbsf, respectively), the water content decreases gradually to about $30 \%$ at 
Site 676

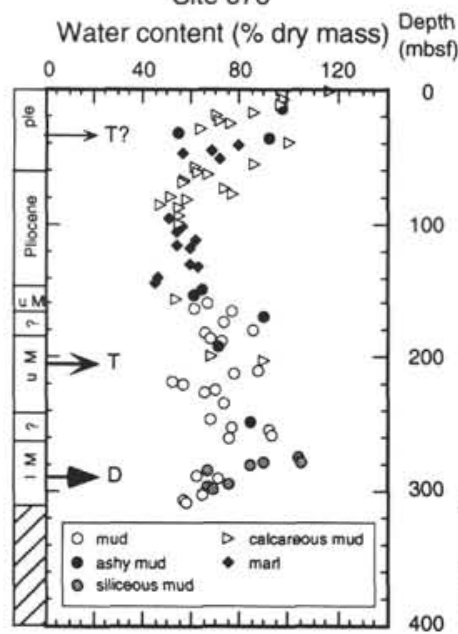

Site 673

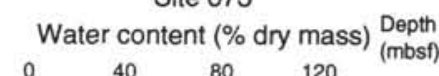

100

200

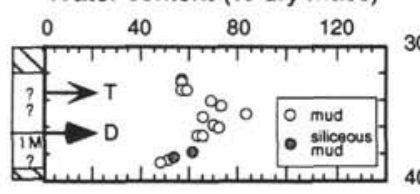

Site 675

Site 675

Water content (\% dry mass)

Site 674

Water content (\% dry mass)
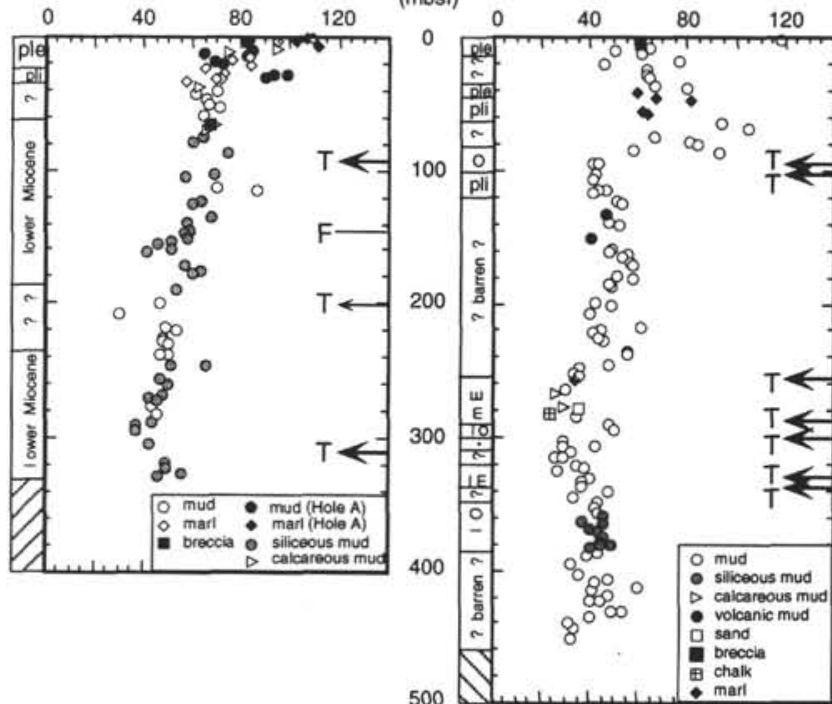

Figure 7. Water content variations vs. depth for Leg 110 sites, including biostratigraphic age, sample lithologies, and structural features. The term mud denotes unmodified mud. The fossil age determinations for Hole 673A and the top of Hole 673B differ: ages are valid for Hole 673B, while Hole 673A intersects older sediment (Miocene and undetermined age). Key to symbols in age columns: $\mathrm{ple}=$ Pleistocene; $\mathrm{pli}=$ Pliocene; $\mathrm{M}=$ Miocene; $\mathrm{O}=$ Oligocene; $\mathrm{E}=$ Eocene; one star $=$ Miocene or Eocene $(?) ; \mathrm{l}=$ lower $; \mathrm{m}=$ middle; $\mathrm{u}=$ upper. Key to structure symbols: $\mathrm{D}=$ décollement; $\mathrm{T}=$ thrust plane; $\mathrm{T}$ ? = possible thrust plane; $\mathrm{F}=$ fold axis.

$389.6 \mathrm{mbsf}$ (Fig. 7). The scattered water content values of the upper zone (128-168 mbsf) are related to a change in lithology, whereas the deeper zone with scattered water content values (285-310 mbsf) coincides with a section of sediments that have steeper dips and more frequent faults per meter. Drilling penetrated the second and third major thrust zones at about $389 \mathrm{mbsf}$ and $447 \mathrm{mbsf}$, respectively. Higher water content values $(42 \%-60 \%)$ characterize the interval from 389.6 to $447 \mathrm{mbsf}$, while the water content generally increases from $39 \%$ to $70 \%$ between 447 and 491.7 mbsf. The décollement zone was intersected between 491.7 to 529.7 mbsf and comprises radiolarianbearing claystone with scaly fabrics. The water content ranges between $57 \%$ to $31 \%$ in the décollement (Fig. 7). The sediment underlying the décollement is composed of alternating barren claystone, calcareous claystone/mudstone, and marlstone (529.7-681.7 mbsf) mudstone of undetermined age (681.7-691.2 mbsf). The water content measured displays a clear but slightly scattered downhole trend in these relatively undeformed sequences and decreases from $48 \%$ to $33 \%$ at sub-bottom depth.

\section{Sites 673 and 674: Lower Slope}

Sites 673 and 674 are closer to the island arc than the other Leg 110 sites, at distances of 13 and $18 \mathrm{~km}$, respectively, west of the deformation front (Fig. 4B). The main lithologies for both sites are marl and partly siliceous and calcareous mud.

\section{Drilling Results from Site 673}

The top interval from 0 to 74 mbsf contains water content measurements from Holes 673A ( $0-36 \mathrm{mbs})$ and B (0-330.6 mbsf; Fig. 7). Although closely situated, the sediment type, age, and water content variations are clearly different between the two holes. At Hole $673 \mathrm{~A}$ the sediments are composed of mud and marl of Miocene and unknown age, with a water content scattered from $64 \%$ to $106 \%$. In 
contrast, Hole 673B is composed of calcareous mud and marl of Pleistocene age with a rapid decrease in water content from $108 \%$ at the surface to $66 \%$ near 74 mbsf (Fig. 7). A generally decreasing water content trend (Fig. 7), from $64 \%$ to $36 \%$ occurs from 74 to 300 mbsf, which is composed mainly of siliceous claystone and mudstone. Locally, water content variations that are seen in this interval can generally be correlated with structural features. A first major thrust zone was penetrated in a zone of low recovery at about $95 \mathrm{mbsf}$. An interval with slightly more scattered water content values was observed between 95 mbsf and $145 \mathrm{mbsf}$. The water content drops by as much as $20 \%$ in a 20 -m-thick band below a fold axis at 145 mbsf, and a shift in the water content from $46 \%$ to $29 \%$ occurs across a major thrust zone at 205 mbsf (Fig. 7). A third major thrust zone (at $311 \mathrm{mbsf}$ ) is, in contrast, associated with a small spike in the water content from $42 \%$ at 305 mbsf to $48 \%$ at 319 mbsf, below which the water content ranges from $45 \%$ to $55 \%$ to the sub-bottom depth.

\section{Drilling Results from Site 674}

Water content values are scattered in the upper $90 \mathrm{~m}$ of Site 674 , which is composed of calcareous or siliceous mud, marl, carbonatefree breccia, and carbonate-free clay, and ranges from $35 \%$ to $118 \%$ (Fig. 7). A distinct drop to lower water content values (to $41 \%$ ) occurs in the thrust zone from 92 to $103 \mathrm{mbsf}$. In the sedimentary package between the first major thrust zone (92-103 mbsf) and the second thrust zone ( $255 \mathrm{mbsf}$ ), composition is mostly mudstone and claystone that are slightly siliceous at the top and calcareous at the base, with water content values ranging from $33 \%$ to $60 \%$ along a slightly decreasing trend. Below the second thrust zone, the water content drops to about $30 \%$ and stays fairly constant down to a third major thrust zone at $285 \mathrm{mbsf}$. Four thrust zones were intersected between 285 and 339 mbsf (at 285, 301, 333, and 339 mbsf; Fig. 7). A spike from about $30 \%$ to $47 \%$ and $49 \%$ water content is observed between the thrust zones at 285 and 301 mbsf; between 301 and 333 mbsf, water content values become more scattered and range from $25 \%$ to $42 \%$; and between 333 and 339 mbsf, only one water content measurement of $36 \%$ exists. The water content values display a subtle increasing trend down to $436 \mathrm{mbsf}$, below which three lower water content values were measured. The water content ranges from $31 \%$ to $59 \%$ between the last major thrust zone (at $339 \mathrm{mbsf}$ ) and the sub-bottom depth.

\section{STATISTICAL ANALYSES}

In general, the comparison of water content with depth (Fig. 8) reveals that the water content is lowest in the cores from Leg 134, intermediate in the cores from Leg 131, and highest in the cores from Leg 110. Furthermore, the water content variation in the upper $200 \mathrm{~m}$ of sediment is greatest for Leg 110, somewhat decreased for Leg 131, and smallest for Leg 134. Due to these observed trends, statistical analyses were considered necessary in order to quantify the data. The lithology was interpreted to be directly related to the water content and was therefore used as one of the main parameters in the statistical analysis. The analyses were made on the sand-sized and mud-sized sediment types (Table 1), and the mud-sized sediment was further subdivided on the basis of composition. Because of the sparse data, calcareous volcanic mud was not included in the statistical analysis. The statistical treatment was made by using the General Linear Model procedure in the Statistical Analyses System environment (SAS 6.03). The program includes parameter estimates of a simple linear regression model, analyses of the variance, testing of the heterogeneity of the water content gradients, and covariance analyses.

\section{Parameter Estimates and Analyses of the Variance}

The program calculates $A$ (average water content value at the seafloor) and $B$ (the water content gradient), with their standard errors for

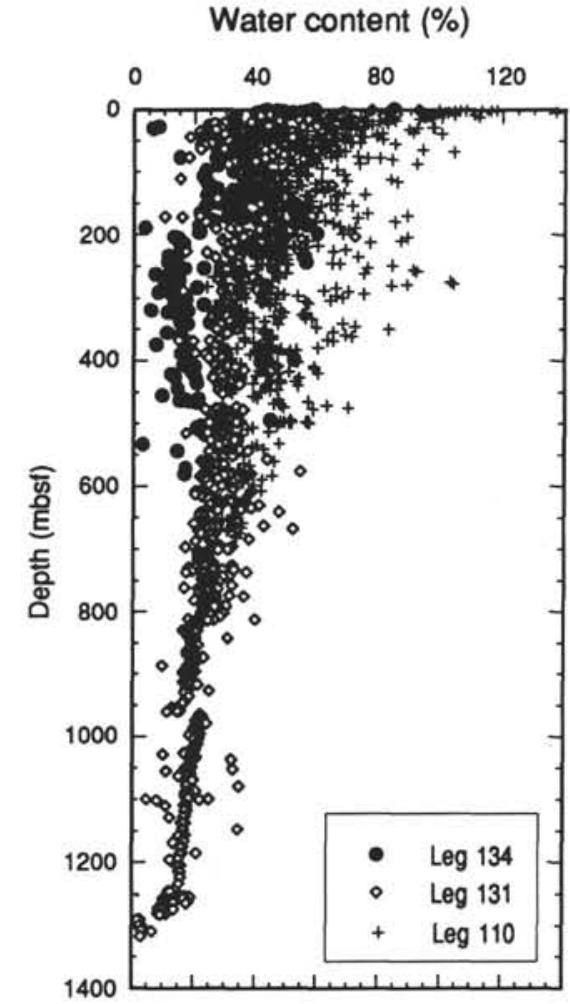

Figure 8. Comparison of water content vs. depth for accretionary-prism sediment for Legs 134, 131, and 110.

the linear regression model $Y=A+B Z$, where $Y$ is the water content and $Z$ is the depth. The coefficient of determination $(\mathrm{CoD})$ gives an estimation of the adaptability of the data to the model. CoD varies between $0 \%$ to $100 \% ; \mathrm{CoD}=0 \%$ means that the data show no linearity with depth; $\mathrm{CoD}=100 \%$ means that the data align perfectly along the given linear model. CoD values of $30 \%$ to $60 \%$ suggest that the curve fit is moderate, whereas CoD's greater than $60 \%$ are considered to have good fit. The significance level of estimates (SLE) for the water content gradient is given in the analysis of the variance. SLE indicates whether the data agree with the calculated water content gradient $(B \pm$ standard error) or not. If SLE is less than $5 \%$, the water content gradient is considered to be statistically confirmed. On the other hand, a high SLE value does not necessarily favor a nonlinear water content distribution, since lack of data or a short length interval results in high SLE values. The reliability of the statistics is directly related to the number of observations and to the length of the depth interval in which the measurements occur. We consider our statistical results to be conclusive if there are more than 20 measurements distributed over a depth interval of at least $100 \mathrm{~m}$. In Tables 2, 3, and 4, the less reliable determinations are shown in italic.

The water content variation with depth was compared with a linear regression model for each mud- and sand-sized sediment type at all sites. If the water content data of a certain sediment type correlates with the regression model, there is a linear change of water content with depth for that sediment type. In a geological sense, it implies that the water content values in the sediment type are less affected by tectonic thickening (i.e., presence of thrust zones). On the other hand, if the water content data of a sediment type is nonlinearly distributed with depth, it indicates that the sediment type is distributed over an interval intersected by thrust faults. It is also possible that a certain sediment type has a nonlinear water content distribution with depth in untectonized sediment, particularly if the samples originate from the upper part of a sediment column. 
Table 2. Results of parameter estimates and variance analyses. Sediment types and sites that have a good adaptation of the water content data to the linear-regression model.

\begin{tabular}{lccrccc}
\hline \multicolumn{1}{c}{ Sediment type } & Leg & Site & No. & CoD & SLE & Regression model \\
\hline Sand sized & 134 & 830 & 18 & 73 & 0.01 & $(37.2 \pm 3.1)-(0.09 \pm 0.01) \mathrm{Z}$ \\
Mud sized & 131 & 808 & 792 & 63 & 0.01 & $(46.6 \pm 0.6)-(0.03 \pm 0.001) \mathrm{Z}$ \\
Unmodified mud & 131 & 808 & 766 & 62 & 0.01 & $(46.7 \pm 0.6)-(0.03 \pm 0.001) \mathrm{Z}$ \\
Volcanic mud & 131 & 808 & 20 & 94 & 0.01 & $(68.4 \pm 3.1)-(0.04 \pm 0.003) \mathrm{Z}$ \\
Siliceous mud & 110 & 676 & 7 & 67 & 1.26 & $(469 \pm 110)-(1.35 \pm 0.39) \mathrm{Z}$ \\
Mud sized & 110 & 673 & 65 & 64 & 0.01 & $(76.9 \pm 2.0)-(0.12 \pm 0.01) \mathrm{Z}$ \\
Unmodified mud & 110 & 673 & 26 & 65 & 0.01 & $(80.2 \pm 3.2)-(0.14 \pm 0.02) \mathrm{Z}$ \\
\hline
\end{tabular}

Notes: No. $=$ number of observations; $\mathrm{CoD}=$ coefficient of determination $(\%) ;$ SLE $=$ significance level of parameter estimates (\%); Regression model calculated by $Y=A+B Z$. Statistically indefinite results (i.c., analyses comprising less than 20 observations) are shown in italic.

Table 3. Results of parameter estimates and variance analyses. Sediment types and sites that have a nonlinear water content distribution with depth.

\begin{tabular}{lllrrrr}
\hline \multicolumn{1}{c}{ Sediment type } & Leg & Site & No. & CoD & SLE & \multicolumn{1}{c}{ Regression model } \\
\hline Mud sized & 134 & 827 & 83 & 5.2 & 3.8 & $(40 \pm 1)+(0.02 \pm 0.01) \mathrm{Z}$ \\
Volcanic mud & 134 & 827 & 60 & 5.1 & 8.0 & $(40 \pm 1)+(0.02 \pm 0.01) \mathrm{Z}$ \\
Sand sized & 134 & 827 & 8 & 11.6 & 40.9 & $(-15 \pm 33)+(0.09 \pm 0.10) \mathrm{Z}$ \\
Sand sized & 131 & 808 & 44 & 0.8 & 57.1 & $(33 \pm 2)-(0.01 \pm 0.01) \mathrm{Z}$ \\
Mud sized & 110 & 676 & 66 & 0.2 & 72.9 & $(74 \pm 4)-(0.01 \pm 0.02) \mathrm{Z}$ \\
Unmodified mud & 110 & 676 & 24 & 2.0 & 49.8 & $(78 \pm 11)-(0.03 \pm 0.05) \mathrm{Z}$ \\
Calcareous mud & 110 & 676 & 25 & 15.0 & 5.1 & $(80 \pm 6)-(0.13 \pm 0.06) \mathrm{Z}$ \\
$\quad$ Volcanic mud & 110 & 676 & 8 & 10.3 & 7.3 & $(80 \pm 8)-(0.04 \pm 0.05) \mathrm{Z}$ \\
Mud sized & 110 & 675 & 15 & 5.4 & 38.8 & $(99 \pm 41)-(0.10 \pm 0.12) \mathrm{Z}$ \\
$\quad$ Unmodified mud & 110 & 675 & 13 & 2.0 & 63.3 & $(87 \pm 48)-(0.07 \pm 0.14) \mathrm{Z}$ \\
Unmodified mud & 110 & 676 & 83 & 26.6 & 0.01 & $(65 \pm 4)-(0.04 \pm 0.01) \mathrm{Z}$ \\
Siliceous mud & 110 & 674 & 9 & 7.6 & 44.0 & $(-15 \pm 4)+(0.12 \pm 0.14) \mathrm{Z}$ \\
\hline
\end{tabular}

Notes: No. $=$ number of observations: $\mathrm{CoD}=$ coefficient of determination $(\%)$ : SLE = significance level of parameter estimates (\%): Regression model calculated by $Y=A+$ $B Z$. Statistically indefinite results (i.e., analyses comprising less than 20 observations) are shown in italic.

\section{Results}

The water content data can be divided into three groups. The first group has water content values that clearly correlate with the regression model ( $\mathrm{COD}>60 \%$ and SLE $<5 \%$; Table 2$)$, the second group has no correlation with the regression model $(\mathrm{CoD}<30 \%$; Table 3$)$, and the third group shows moderate correlation with the regression model $(60 \%>\mathrm{CoD}>30 \%$ or SLE $>5 \%$; Table 4$)$.

Leg 134 Sites

At Site 827 , the water content values in the mud-sized sediment type have no correlation with a regression model (Table 3). Mud-sized sediment is composed of volcanic-, calcareous-, and calcareous volcanic mud (Fig. 5). Volcanic mud was sampled from the seafloor to 252 mbsf. Across the thrust zone at 160 mbsf, it is a change in the water content-depth variation. This change, which is caused by tectonic thickening, cannot be represented by a single regression model (Table 3). The results from the calcareous mud and sand-sized sediment types are inconclusive due to the sparse number of data (Tables 4 and 3 ).

At Site 829 , there is a moderate correlation between the regression model and water content values in the mud-sized sediment type (Table 4). Most mud-sized samples are composed of volcanic mud (Fig. 5). Volcanic mud was sampled from the seafloor to $171 \mathrm{mbsf}$ and from 490 to $520 \mathrm{mbsf}$. According to the regression model, there is no major difference between the water content trends in the relatively undeformed volcanic mud (0-171 mbsf) and the highly tectonized volcanic mud (490-520 mbsf; Table 4). The result in the sand-sized sediment types is inconclusive due to the sparse number of data (Table 4).

At Site 830, there is a moderate correlation between the regression model and water content values in the mud-sized sediment type (Table 4). The mud-sized sediment was sampled between the seafloor and 175 mbsf, and all samples are composed of volcanic mud (Fig. 5). Because of normal consolidation of the volcanic mud, the water content values have only a moderate correlation with the regression model (Table 4).
Table 4. Results of parameter estimates and variance analyses. Sediment types and sites that have a moderate adaptation of the water content data to the linear-regression model.

\begin{tabular}{lccrccc}
\hline Sediment type & Leg & Site & No. & CoD & SLE & Regression model \\
\hline Calcareous mud & 134 & 827 & 12 & 36 & 2.88 & $(I 0 I \pm 22)-(0.28 \pm 0.11) \mathrm{Z}$ \\
Mud sized & 134 & 829 & 64 & 34 & 0.01 & $(41 \pm 1)-(0.04 \pm 0.01) \mathrm{Z}$ \\
$\quad$ Volcanic mud & 134 & 829 & 50 & 30 & 0.01 & $(41 \pm 1)-(0.04 \pm 0.01) \mathrm{Z}$ \\
Sand sized & 134 & 829 & 4 & 95 & 5.50 & $(42 \pm 3)-(0.05 \pm 0.01) \mathrm{Z}$ \\
Mud sized & 134 & 830 & 28 & 38 & 0.03 & $(43 \pm 3)-(0.18 \pm 0.04) \mathrm{Z}$ \\
$\quad$ Volcanic mud & 134 & 830 & 28 & 38 & 0.03 & $(43 \pm 3)-(0.18 \pm 0.04) \mathrm{Z}$ \\
Calcareous mud & 131 & 808 & 3 & 89 & 5.58 & $(48 \pm 5)-(0.03 \pm 0.01) \mathrm{Z}$ \\
Mud sized & 110 & 671 & 160 & 41 & 0.01 & $(70 \pm 2)-(0.06 \pm 0.01) \mathrm{Z}$ \\
Calcareous mud & 110 & 671 & 66 & 47 & 0.01 & $(74 \pm 4)-(0.09 \pm 0.01) \mathrm{Z}$ \\
Volcanic mud & 110 & 671 & 6 & 4 & 12.9 & $(72 \pm 8)-(0.08 \pm 0.05) \mathrm{Z}$ \\
Siliceous mud & 110 & 673 & 35 & 49 & 0.01 & $(69 \pm 3)-(0.08 \pm 0.01) \mathrm{Z}$ \\
Calcareous mud & 110 & 673 & 4 & 44 & 21.9 & $(84 \pm 9)-(0.29 \pm 0.19) \mathrm{Z}$ \\
Mud sized & 110 & 674 & 105 & 36 & 0.01 & $(65 \pm 3)-(0.07 \pm 0.01) \mathrm{Z}$ \\
Unmodified mud & 110 & 674 & 89 & 38 & 0.01 & $(65 \pm 3)-(0.07 \pm 0.01) \mathrm{Z}$ \\
\hline
\end{tabular}

Notes: No. $=$ number of observations; $\mathrm{CoD}=$ coefficient of determination $(\%) ; \mathrm{SLE}=$ significance level of parameter estimates (\%); Regression model calculated by $Y=A+B Z$. Statically indefinite results (i.c., analyses comprising less than 20 observations) are shown in italic.

There is a good correlation between the regression model and water content values in the sand-sized sediment type (Table 2). Since the 18 samples of sand-sized sediment are evenly distributed over more than $300 \mathrm{~m}$ of the sediment column, the regression model is considered to be reliable (Fig. 5). The sand-sized samples are composed of two facies, namely unlithified, volcanic sandy turbidites (20-130 mbsf) and brittle deformed, altered epiclastic sandstone (175-350 mbsf). There were no indications of tectonic thickening in the sediment column at Site 830. The linear water content-depth function in sandsized sediment indicates that the volcanic mud and volcanic sandy turbidites have been deposited directly upon the epiclastic sandstone.

\section{Leg 131, Site 808}

At Site 808 there is a good correlation between the regression model and water content values in the mud-sized sediment type (Table 2). Mud-sized sediment is composed of unmodified-, volcanic-, and calcareous mud (Fig. 6). There is good correlation between the regression models and water content values in unmodified- and volcanic mud (Table 2). However, the regression models for these two sediment types are clearly different. The calculated water content range at the seafloor is more than $20 \%$ higher, and the water content gradient is slightly steeper in volcanic mud than in unmodified mud. Unmodified mud was sampled at all depths (Fig. 6), while volcanic mud mostly was sampled below the décollement. Negative offsets of the water content were observed within the frontal thrust zone (357-395 mbsf) and within the décollement ( $950-965 \mathrm{mbsf})$, and a positive offset of the water content trend occurred below the décollement. These offsets were not significant enough to be distinguished in the regression model for unmodified mud. On the other hand, the positive offset of the water content trend below the décollement is reflected in the regression model for volcanic mud. Although volcanic mud has a linear water content-depth function, the high water content values indicate that volcanic mud is affected by tectonic thickening (see "Water Content Variation Related to Tectonic Stress," this chapter). The result in the calcareous mud sediment type is inconclusive due to the sparse number of data (Table 4). The water content values in the sand-sized sediment have no correlation with a regression model (Table 3 ). Sand-sized sediment was mainly sampled from the seafloor to about $100 \mathrm{mbsf}$ (Fig. 6), but samples also occur irregularly down to about $800 \mathrm{mbsf}$. The nonlinear water content distribution in the upper $350 \mathrm{~m}$ is largely a function of grain size (Moran et al., 1993), while water content variation in the deeper parts also may be affected by tectonic thickening.

\section{Leg 110 Sites}

At Site 676, the water content values in the mud-sized sediment type have no correlation with a regression model (Table 3 ). Mud-sized sediment is composed of unmodified, calcareous, siliceous, and vol- 
canic mud (Fig. 7). The water content values in unmodified and calcareous mud samples follow a wide-ranging zigzag pattern with depth. These variations are related to grain-size variations, as well as tectonic thickening and other parameters (e.g., cementation). The results in siliceous and volcanic mud are inconclusive due to the sparse number of data (Tables 2 and 3 ).

The results at Site 675 are inconclusive due to the sparse number of data (Table 3). At Site 671, there is a moderate correlation between the regression model and water content values in the mud-sized sediment type (Table 4). Mud-sized sediment is composed of calcareous, unmodified, and volcanic mud (Fig. 7). The majority of the calcareous mud samples occur between the seafloor and 389 mbsf. Because of normal compaction of the calcareous mud and tectonic thickening, the water content values have only a moderate correlation with the regression model (Table 4). The water content values in unmodified mud have no correlation with a regression model (Table 3 ). The majority of the unmodified mud samples occur in the thrusted sequences below the second major thrust zone (at $389 \mathrm{mbsf}$ ). The nonlinear water content variation with depth is probably mostly related to tectonic thickening. The result in volcanic mud is inconclusive due to the sparse number of data (Table 4).

At Site 673 there is a good correlation between the regression model and water content values in the mud-sized sediment type (Table 2). The mud-sized sediment is composed of unmodified, siliceous, and calcareous mud (Fig. 7). Unmodified mud was mainly sampled from the seafloor to $70 \mathrm{mbsf}$, and from 200 to $240 \mathrm{mbsf}$. According to the regression model (Table 2 ), there is no difference between the undeformed unmodified mud ( $0-70 \mathrm{mbsf})$ and the underthrusted sequence (200-240 mbsf). There is a moderate correlation between the regression model and water content values in siliceous mud (Table 4). Siliceous mud was sampled from $74 \mathrm{mbsf}$ to sub-bottom depth (Fig. 7), and this sediment appears to be more affected by tectonic thickening than unmodified mud. The result in the calcareous mud sediment type is inconclusive due to the sparse number of data (Table 4).

At Site 674 there is a moderate correlation between the regression model and water content values in the mud sized sediment type (Table 4). Mud-sized sediment is composed of unmodified and siliceous mud (Fig. 7). Unmodified mud was sampled at all depths. This indicates that the unmodified mud samples are slightly affected by tectonic thickening. The result in siliceous mud is inconclusive due to the sparse number of data (Table 3 ).

\section{Heterogeneity of Water Content Gradients}

The assumption for the heterogeneity analysis is that the variance is the same for all sites and that the water content varies linearly with depth. Water content gradients $(\mathrm{B} \pm$ standard error) are gathered with respect to the sediment type and compared among the sites. In this way, it is possible to identify if the water content variation in a certain sediment type has a comparable gradient at different sites. If the significance level of the heterogeneity (SLH) is greater than $5 \%$, the water content gradients are considered to be similar among the sites.

\section{Results}

Calculations resulted in low SLH values $(<1 \%)$ for the mud-sized, sand-sized, unmodified, siliceous, and volcanic mud sediment types. The dissimilarities of water content gradients in these sediment types indicate that the tectonic setting has a strong influence on the dewatering. The comparison of heterogeneity of water content gradients in the calcareous mud sediment type resulted in a higher SLH value $(33 \%)$. Thus, in spite of the location, water content values at the inves- tigated sites have a similar water content gradient in calcareous mud.

\section{Covariance Analyses}

The average water content values are gathered with respect to the sediment type and compared among the sites. The boundary condition
Table 5 . Summary of significance levels $>5 \%$ obtained by the Least Square Mean procedure at covariance analyses for the different sediment types.

\begin{tabular}{lccccccc}
\hline Sediment type & Leg 1 & Site 1 & No. & Leg 2 & Site 2 & No. & SLC \\
\hline Mud sized* & 110 & 675 & 15 & 110 & 676 & 66 & 13.4 \\
& 134 & 827 & 83 & 131 & 808 & 792 & 6.9 \\
Unmodified mud* $^{*}$ & 110 & 675 & 13 & 110 & 676 & 24 & 21.4 \\
Siliceous mud* $^{*}$ & 110 & 673 & 35 & 110 & 674 & 9 & 28.5 \\
Calcareous mud & 110 & 673 & 4 & 110 & 676 & 25 & 96.6 \\
& 131 & 808 & 3 & 110 & 676 & 25 & 88.0 \\
& 131 & 808 & 3 & 110 & 673 & 4 & 87.8 \\
& 110 & 671 & 66 & 110 & 673 & 4 & 62.0 \\
& 131 & 808 & 3 & 110 & 671 & 66 & 52.4 \\
& 110 & 671 & 66 & 110 & 676 & 25 & 31.0 \\
& 134 & 827 & 12 & 131 & 808 & 3 & 12.0 \\
Volcanic mud* & 134 & 827 & 12 & 110 & 673 & 4 & 11.4 \\
Sand sized* & 131 & 808 & 20 & 110 & 671 & 6 & 99.0 \\
& 134 & 827 & 7 & 134 & 830 & 18 & 54.0 \\
& 134 & 829 & 4 & 134 & 830 & 18 & 31.8 \\
& 134 & 827 & 7 & 134 & 829 & 4 & 17.5 \\
\hline
\end{tabular}

Notes: No. $=$ number of observations; SLC $=$ significance level of covariance analyses $(\%) ;{ }^{*}=$ sediment types where the water content gradients are not similar among the sites.

is that the water content gradients for all sites are the same (determined from heterogeneity analysis). The program compares the average water content range at the different sites and gives the significance level of covariance (SLC). In this way, it is possible to get indications that data from different sites actually may be more similar than previously shown in the parameter estimates analyses. The average water content values at two sites are considered to be similar when the SLC value is greater than $5 \%$.

\section{Results}

Pairs of sites with SLC greater than 5\% in the covariance test are listed in Table 5. Although, the boundary condition for the covariance analyses only was fulfilled for the calcareous mud sediment type, all site pairs with SLC $>5 \%$ are listed in the Table 5 . The average water content is similar among most sites in calcareous mud. The only exceptions occur when the average water content at Site 827 is compared with those at Sites $671($ SLC $=4.6 \%)$ and $676($ SLC $=$ $1.4 \%$ ). Closely located sites may have similar water content ranges, although their water content gradients differ. The water content ranges at Sites 675 and 676 are similar in mud-sized sediment and unmodified mud, water content ranges at Sites 673 and 674 are similar in siliceous mud, and all Leg 134 sites have a similar water content range in sand-sized sediment. Sites drilled at different legs may also have similar water content ranges: the water content ranges in mud-sized sediment are similar at Sites 827 and 808, and the ranges in volcanic mud are similar at Sites 808 and 671.

\section{Summary of the Statistical Results}

The water content variation with depth in most sediment types has no, or moderate, correlation with linear regression models at the investigated sites (Tables 3 and 4 ). The presence of thrust zones often results in offsets of the water content depth-function. Furthermore, changes in the water content variation with depth may also be due to small grainsize variations within the sediment types, as well as other factors (e.g., cementation). These offsets cannot be represented by a single linear regression model. Linear water content-depth functions were calculated for three sites (Table 2). Water content varies linearly with depth in sediment composed of unmodified mud at Sites 808 and 673, in volcanic mud at Site 808, and in sand-sized sediment at Site 830 .

The similarities among the sites were tested by comparing their water content gradient and their average water content. Most sediment types have different water content distributions at the respective sites. The only exception occurs in calcareous mud sediment, where similar water content gradients and average water content values were calculated at the sites. 


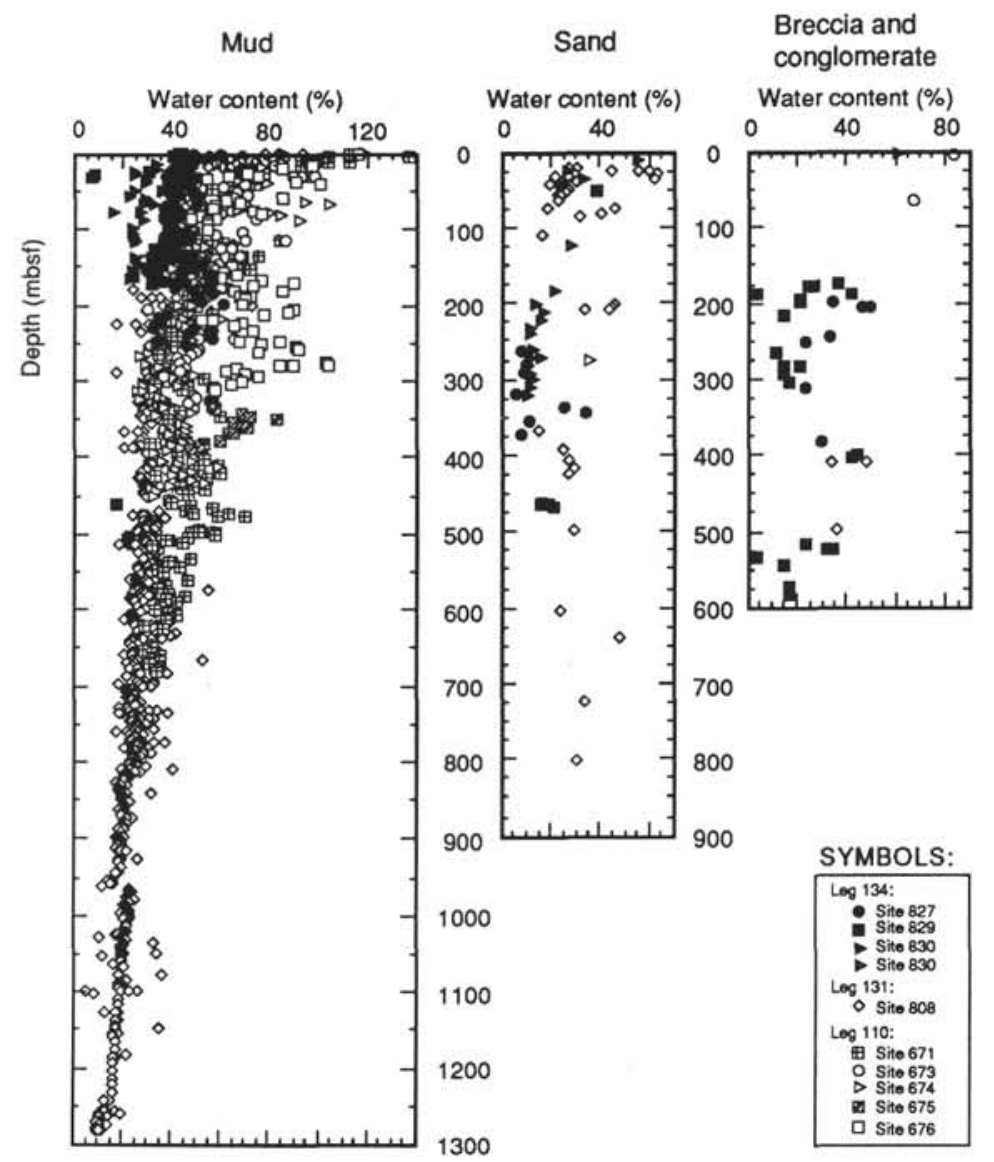

Figure 9. Water content vs. depth for mud-sized sediment, sand-sized sediment, and breccia and conglomerate. The subdivision with respect to modifiers of the mud-sized samples is shown in Figure 10. The sand samples are composed of volcanic sand (Leg 134 sites), calcareous volcanic sand (Site 830), and unmodified sand (Sites 808 and 674),

\section{DISCUSSION}

\section{Water Content Variation Related To Sediment Types}

Water content variations in different sediment types at the sites and, to some extent, among the sites were presented in the "Statistical Analyses" section. This section will mainly consider comparisons and interpretations of water content variations in the sediment types among the sites. Water content variations are largely a function of grain-size and lithology. The sediment types presented in Table 1 comprise interpretation of the sample lithology and the grain size. By dividing the existing measurements according Table 1, we can begin to determine how much of the water content variation among the sites (Fig. 8) is due to lithology and grain-size changes, and how much is due to tectonic effects.

\section{Mud-sized Sediment}

Linear water content-depth functions were calculated at Site 808 and Site 673. Mud-sized sediment is drier at Site 808 (water content is about $30 \%$ lower at the seafloor), whereas the water content gradient at the seafloor is four times greater at Site 673 (Table 2; Fig. 9 ). The water content variance among the sites is more distinct in the shallower parts of the sediment column. At similar depth intervals (less than $300 \mathrm{mbsf}$ ), the mud-sized sediment at Site 830 is distinctly drier than at Site $676(15 \%-35 \%$ and $50 \%-95 \%$, respectively).

Previous studies (e.g., Trask, 1932; Hedberg, 1936) showed that the initial porosity, and thus water content, increases faster with a decrease of the diameter in finer grained sediment (diameter $<0.030$ $\mathrm{mm})$ than in coarser sediment $(>0.030 \mathrm{~mm})$. The latter author explained this relation as being due to an increase of the total specific area with decreasing grain size. The scatter of the water content values, especially in sediment drilled on Leg 110 might, therefore, reflect small changes in grain size in the finer grained samples.

\section{Unmodified Mud}

The different water content trends at the respective sites (Tables 2,3 , and 4, and Fig. 10) indicate that the position of the sites relative to the arc influences the dewatering pattern in unmodified mud. The statistical analyses suggest nonlinearity close to the deformation front at the Barbados Ridge accretionary prism (Sites 676 and 671). Toward the island arc (i.e., Sites 673 and 674), the data can be represented by linear-regression model of good, respectively moderate quality. The statistical analyses suggest that the sediment at Site 674 (closest to the island arc) is drier than at Site 673 (Tables 2 and 4).

\section{Siliceous Mud}

Siliceous mud was sampled only in thrusted sediment (Sites 673 and 674) and in the décollement (Sites 676 and 675). At comparable depths, Figure 10 shows that the samples at Sites 676 and 675 have considerably higher water content than those at Sites 673 and 674 . This peak in water content values probably reflects fluid migration in the décollement (Fig. 7). 

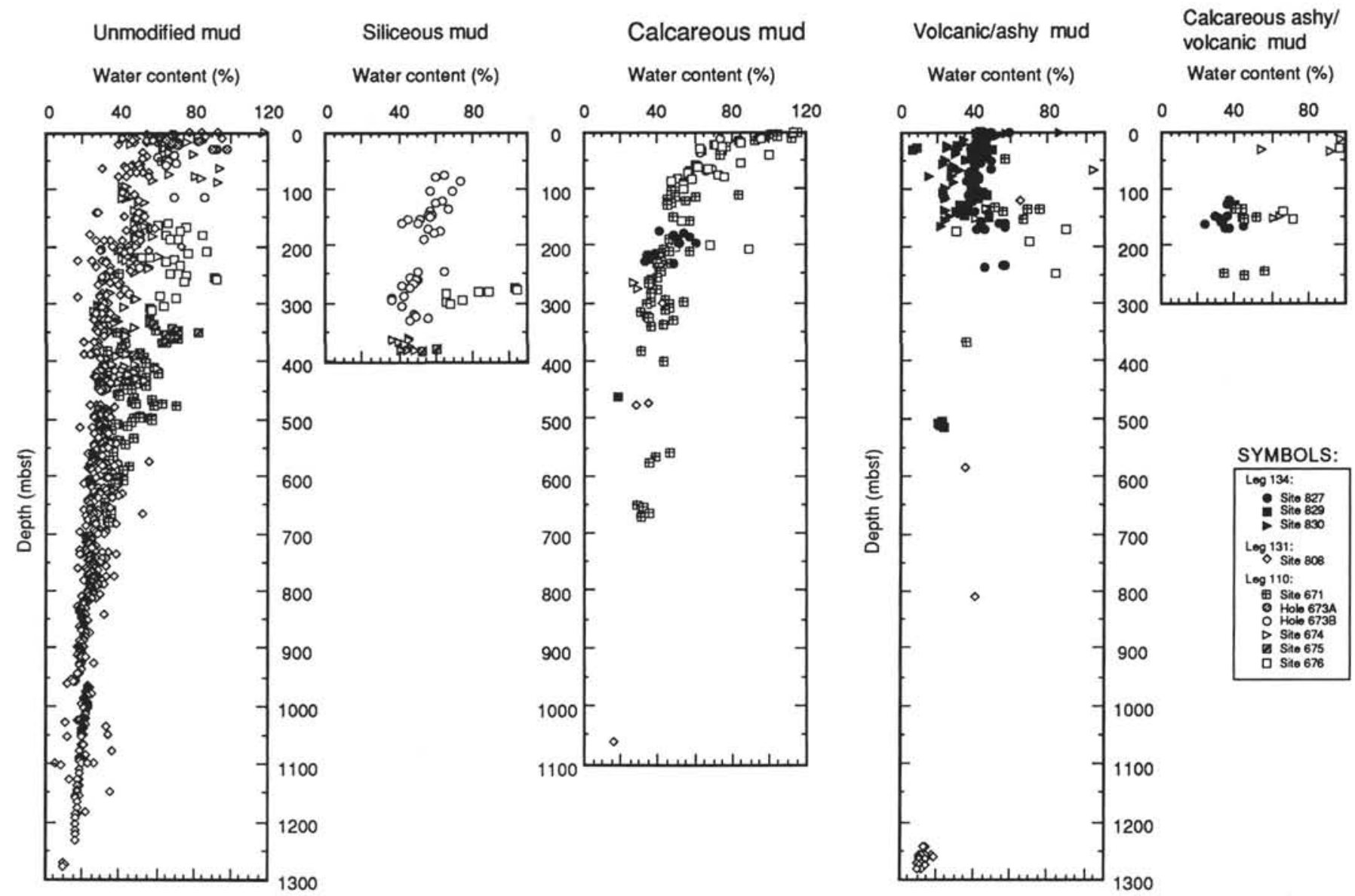

Figure 10. Water content vs. depth for mud-sized samples, which have been sorted with respect to these modifiers: unmodified mud, siliceous mud, calcareous mud, volcanic and ashy mud, and calcareous volcanic and volcanic calcareous mud.

\section{Calcareous Mud}

The water content variation in calcareous-mud sediment is much different compared to those presented above (Fig. 10). This observation is consistent with previous studies of the physical characteristics of calcareous sediment, that include studies of compaction, void ratios and sedimentary structure relationship to overburden pressure. Mechanical compression tests have shown that calcareous mud compacts less than noncalcareous mud (Terzaghi, 1940; Robertson, 1967). Calcareous clays have been shown to have higher void ratios than noncalcareous clays at similar load (Morelock and Bryant, 1972). Sedimentary structures developed in calcareous clays are capable of supporting a greater overburden pressure with little or no evidence of additional compaction in comparison to carbonate-free clays (Richards and Hamilton, 1967). Apparently, except for Sites 827 and 829, the convergence rate and the stress field in the sites investigated have little or no effect on water content in sediment with a high calcareous mud content. Although drilling disturbance is a possibility, the low water content at Site 827 and 829 samples may reflect different composition and coarser texture of the sediment. However, the rapid convergence rate of the New Hebrides Island Arc (13 cm/yr) is more than three times as fast as the rates of the Nankai Trough $(4 \mathrm{~cm} / \mathrm{yr})$ and Barbados Ridge $(2 \mathrm{~cm} / \mathrm{yr})$. Rapid convergence, together with the subduction of the NDR, may compact the structure of the calcareous mud sediment and actually change the water content by tectonic dewatering.

Unfortunately, the degree of cementation was not determined for the samples in this study. Therefore, we cannot evaluate the effect of cementation on water content. Carbonate-bearing sediment has a great tendency to cement, which probably affected the magnitude of the water content values. Cement increase the strength of the sediment, but does not necessarily decrease the pore volume. In thrusted sediment, this results in high water content values of samples compared to their depth of burial. The scatter of water content values in carbonate-bearing sediment, especially at Leg 110, might reflect variation in cementation.

\section{Volcanic and Ashy Mud}

Statistical analyses indicate that only the volcanic and ashy mud sediment type at Site 808 correlates with the linear-regression model. The distributions of water content measurements from the NDR (Sites 827 and 829) and SDC (Site 830) are segregated (Fig. 10). At comparable depths in the upper 150 mbsf, water content at Site 830 generally is about $10 \%$ less than at Sites 827 and 829 . At Sites 827 and 829 , the first signs of tectonic deformation occur below 107 and 80 mbsf, respectively, while sediment at Site 830 is relatively undeformed above $175 \mathrm{mbsf}$. This implies that the interstitial permeability of the volcanic mud at Site 830 is sufficient to transport the squeezed water to the seafloor, while fractures are developed to accommodate the dewatering of sediment from deeper levels at Sites 827 and 829 . The scattered water content values at the latter two sites might be related to tectonic deformation and/or reflect an increase in the $\mathrm{CaCO}_{3}$ content (Figs. 3 and 4 of Leonard and Ask, this volume).

\section{Calcareous-volcanic and Volcanic-calcareous Mud}

Calcareous-volcanic and volcanic-calcareous-mud was sampled at Sites $827,671,674$, and 676 (Fig. 10). The water content at Site 827 
is less at all depths. Site 671 measurements are of the second smallest order, while measurements at Sites 674 and 676 overlap each other.

\section{Sand, Breccia, and Conglomerate}

In the sand-sized sediment type (Fig. 9), the water content distribution is characterized by scattered values at all sites and depths, except at Site 830. The water content ranges are similar at all Leg 134 sites (Table 5). The linearity of the water content-depth function at Site 830 supports the interpretation that the sediment is not affected by thrusting (Shipboard Scientific Party, 1992). Furthermore, the very low water content values suggest a higher sand permeability at Site 830 than at Sites 827 and 829 . Our generally poor knowledge of the grain-size distribution of the sand samples at Sites 827 and 829 makes it impossible to distinguish whether the water content scatter shown in Figure 9 is related to tectonic stresses associated with the geographical location of the data, or if it is related to differences in sorting, composition, and degree of lithification.

\section{Carbonate Sediment}

Pelagic sediment was only collected at Sites $827,829,808$, and 674 . These have different compositions and degrees of consolidation (Table 1 and Fig. 11). In chalk samples from Site 829, water content generally is very low $(\approx 15 \%-20 \%)$, though higher values occur in the major thrust zones (Fig. 5). The chalks sampled between 378 and 406 mbsf at Site 829 are interpreted as having originated from the NDR (Reid et al., this volume). A probable parent of these chalks was penetrated and sampled from 69 to 91 mbsf at Site 828, a reference site drilled on the NDR near Sites 827 and 829 (Fig. 12). Thus, sections similar to the firm ooze at Site 828 , which has a water content range of $33 \%$ to $40 \%$, may have been accreted and dewatered and compacted into the chalk at Site 829 , with a water content of about $20 \%$.

\section{Marl and Mixed Sediment}

The marl and mixed sediment display a similar decrease in water content with depth to the calcareous-mud sediment type (Figs. 11 and $10)$. These data support the observation that sediment with a calcareous component is capable of accommodating greater stress than noncalcareous sediment. The only exceptions to this apparently exponentially decreasing water content trend with depth occur in mixed-sediment rocks at Site 829: the lower water content values at Site 829 may indicate a slightly different composition or drilling disturbances, or that the stress regime dewatered the sediment (Fig. 11).

\section{Water Content Variation Related to Tectonic Stress}

\section{Influence at Thrust Zones and Décollements}

All sites investigated here penetrated thrust zones by drilling, except Site 830. Because of their highly fractured nature, these thrust zones are probably more permeable than the surrounding sediment. Thus, higher water content values would be expected within these zones. High, erratic water content values are measured in most, but not all, of these fault zones. Lower water content values were measured in the frontal thrust at Site 808 (Fig. 6), and in some of the thrust zones at Sites 671 and 674 (Fig. 7). This implies that the "wet" thrust zones transport fluids from surrounding sediment units and deeper levels, while the "dry" thrust zones do not transport fluids, or have become inactive after serving as conduits in the past. In three cases, at Sites 827, 829, and 674 (Figs. 5 and 7), we found unusual, large differences in the water content trend across a thrust zone. These offsets are most probably related to lithological changes, since thrust zones generally are associated with juxtaposition of lithology.

The décollement was penetrated at Site 808 and at Sites 671, 675, and 676. Décollements are probably more permeable than the surrounding sediment because of their highly fractured nature. Fluid migration was observed in the décollement at Barbados Ridge (Shipboard Scientific Party, 1988). The décollement at Site 808 appears, however, not to transport fluids. One-dimensional consolidation tests (Moran et al., 1993) have shown that sediment underlying the décollement is severely underconsolidated. The sediment porosity values are much too high for their depth of burial, assuming normal consolidation. From the consolidation tests, Moran et al. (1993) concluded that the décollement at the Nankai Trough is a high-pressure boundary, which prevents drainage of the underlying sediment.

\section{Water Content Variation Across the Accretionary Prism}

Bray and Karig (1985) studied the dewatering processes in several accretionary prisms, including the Nankai Trough and the Lesser Antilles Island Arc (DSDP data). They concluded that dewatering occurs in two ways: (1) as a result of tectonic thickening and (2) as additional dewatering by a steepening of the porosity gradient across the accretionary prism.

The presence of thrust zones show that a sediment column is affected by tectonic thickening. Under-thrusted sediment has been placed at a deeper level than its original depth of burial. If the sediment permeability is high enough and drainage is possible, dewatering will occur until the sediment has equilibrated to the new depth of burial. The strongest evidence of tectonic thickening is the presence of 9 major and 3 minor thrust zones at Site 829 (Fig. 5). On the other hand, no evidence of tectonic thickening was found at Site 830 .

Because the Leg 110 sites transect the prism, we can see if a steepening of the water content gradient occurs across the Barbados Ridge accretionary prism (Fig. 4B). Most samples at Leg 110 are composed of unmodified mud, siliceous mud, calcareous mud, volcanic mud and marl. The calcareous mud and marl sediment types are not influenced by their location in the prism relative to the arc. In contrast, the water content gradients of the remaining samples (unmodified, siliceous, and volcanic mud) have different water contentdepth variations at the respective sites.

Because the only good correlation between the regression model and water content values in unmodified mud was at Site 673 , we cannot use the statistical results to show whether or not there is a steepening of the water content gradient across the prism. Figure 13 shows that water content distributions in unmodified mud from the Barbados Ridge sites form a distinct pattern. Water content measurements at Sites 676 and 675 are characterized by scattered values over the entire depth, whereas the water content values at Sites 671, 673, and 674 are distributed more homogeneously with depth. Furthermore, the highest water content levels are associated with sites close to the deformation front (Sites 676 and 675), and the lowest water content levels are associated with sites further away (Sites 674 and 673; Fig. 13). Thus, in samples composed of unmodified mud, it appears that additional dewatering occurs across the accretionary prism. Lack of data (Fig. 10) prevents us from drawing conclusions about whether there is additional dewatering across the prism in siliceous and volcanic mud samples.

The Vanuatu (Leg 134) sites are located close to the deformation front, rather than along a perpendicular transect as at Barbados Ridge (Figs. 2A and 4B). Sites 827,829 , and 830 were drilled at 4,2 , and 7 $\mathrm{km}$, respectively east of the trace of the subduction zone. Volcanic mud sediment was sampled in the upper sections of the Leg 134 sites. Because the Leg 134 sites were not drilled along a transect across the area, we are unable to observe a steepening of the water content gradient across the accretionary prism of the New Hebrides Island Arc. The water content gradients in the upper 100 to $150 \mathrm{~m}$ are very steep at the three sites (Fig. 10), and the depth distributions of water content differ only in magnitude: water content is about $10 \%$ lower at Site 830 than at Sites 827 and 829 . This may indicate that subduction of the NDR and SDC have altered the change of the water content gradient across the prism observed at other arcs. 


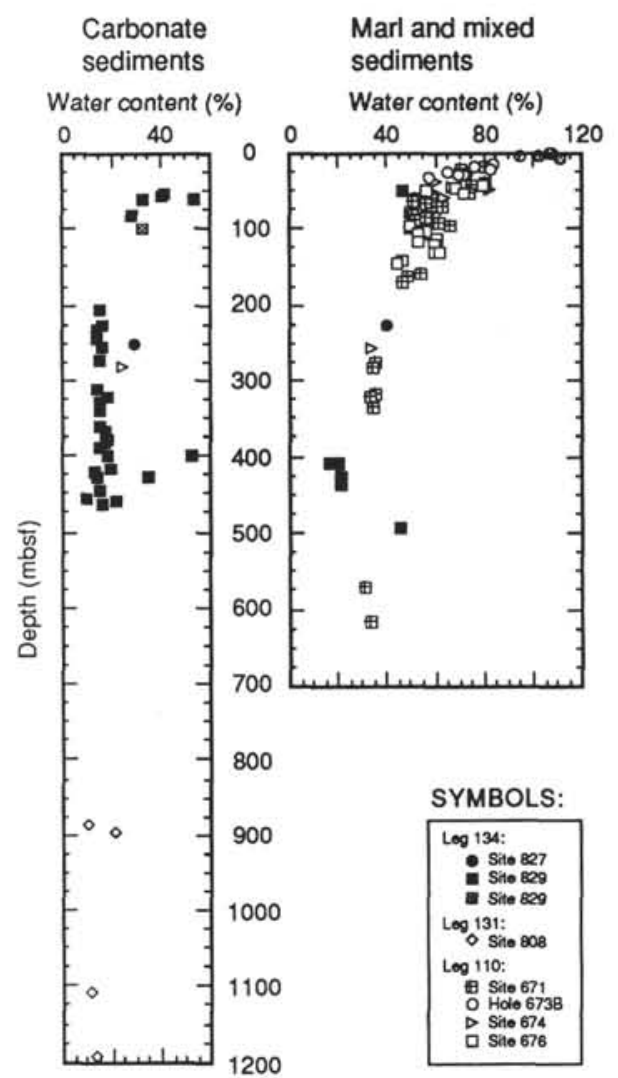

Figure 11. Water content vs. depth for carbonate sediment and marl and mixed sediment. Left: samples are composed of ooze (gray squares for Site 829), chalk (Site 671 and black squares for Site 829), limestone (Site 827), and carbonate (Site 808). Right: samples from Leg 134 are composed of mixed sediment, and samples from Leg 110 consist of marl.

\section{Water Content Variation At Different Convergence Rates}

The water content distributions from Legs 134, 131, and 110 confirm that increasing convergence rates result in smaller water content values for accreted material (Fig. 8). Carson and Berglund (1986) used a sandbox model as an analog to define the pattern of sediment consolidation under horizontal compression and the mechanisms by which dewatering occurs. They determined that the sediment dewaters at different rates, depending on the convergence rate. Most of the water loss occurred near the driving plate of the model in the most deformed region and the amount of dewatering decreased with decreasing convergence rate. It can be implied (Carson and Berglund, 1986) that the observed difference in the water content at the three locations is related to the distinctly higher convergence rate of the New Hebrides Island $\operatorname{Arc}(13 \mathrm{~cm} / \mathrm{y}$.) and the intermediate and lower convergence rates at the Nankai Trough $(4 \mathrm{~cm} / \mathrm{y}$.) and the Barbados Ridge $(2 \mathrm{~cm} / \mathrm{y}$.).

The best illustration of dewatering at different convergence rates is observed in Figure 10 and in the statistical analyses of unmodifiedmud sediment (Table 2). In similar sediment type and at similar depths, Site 808 has lower water content values than Site 673, even though Site 808 is located closer to the deformation front of the Nankai Trough accretionary prism than Site 673 is to the deformation front of the Barbados Ridge.

Carson and Berglund (1986) showed that the greatest water content reduction occurred near the driving plate of their model. The collision between the Bougainville Guyot of the SDC and the New Hebrides Island Arc creates a deformational stress field over an area which is much larger than the area where the NDR and the arc collide (Figs. 2B and 2C). The subducted part of the NDR is uplifting and accreting the Wousi Bank, whereas the Bougainville Guyot has

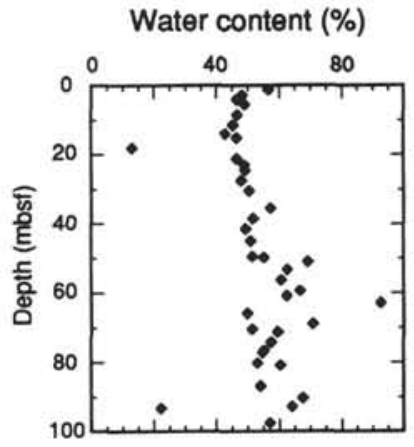

Figure 12. Water content variations vs. depth for Leg 134 Site 828.

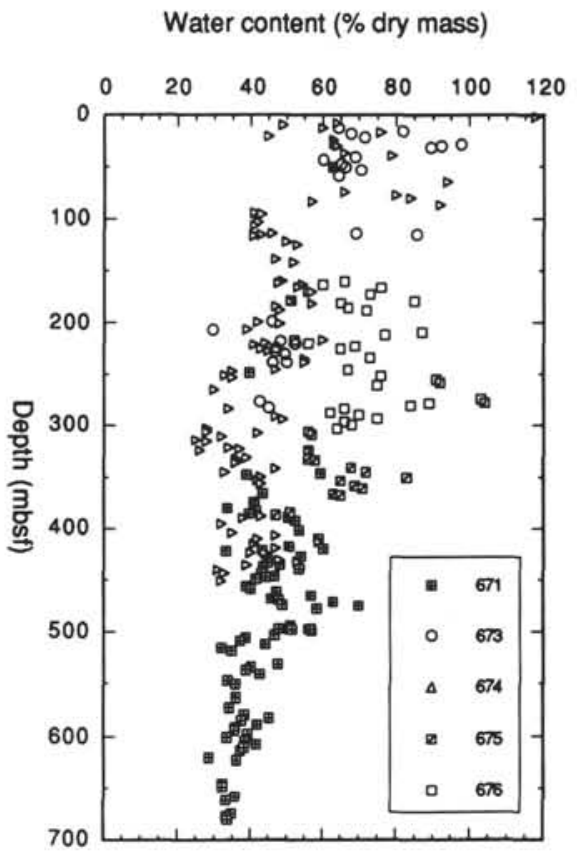

Figure 13. Water content vs. depth for unmodified mud at Leg 110.

indented and foreshortened the sedimentary and volcanic rocks of the forearc by about $10 \mathrm{~km}$ (Fisher et al., 1986). Two samples of unlithified volcanic sediment from above 175 mbsf at Site 830 are very overconsolidated (Leonard, 1991; i.e., the previous in-situ stresses of the sediment are much bigger than the present vertical stress). The larger deformational pressures probably account for the lower water content magnitudes of Site 830 versus Sites 827 and 829 .

\section{CONCLUSIONS}

Water content profiles vary with depth at nine sites from Legs 134 , 131 , and 110 . Generally, the lowest water content values were measured in sediment from the lower trench slope of the Vanuatu accretionary prism. The sediment from the lower trench slope of the Nankai Trough prism has intermediate water content values, and has a uniform water content distribution with depth. The highest and most scattered water content values occur in sediment of the lower trench slope of the Barbados Ridge accretionary prism.

Calcareous sediments (calcareous mud, mixed sediment, and marl) are similarly distributed along an exponentially decreasing water content trend at most sites. In contrast, sediment of other lithologies show clearly different water content distributions with depth at different sites. Water content in calcareous sediment is apparently less affected by tectonic stress than that in other sediment types. Our data support 
the observation that sediment with calcareous component is capable of accommodating greater stress than non-calcareous sediment.

Our results suggest that the following parameters, listed in order of importance, alter the water content for all sediment types, except calcareous sediment:

1. Rapid convergence rates result in increased dewatering of accreting sediment.

2. Thrust zones and décollements are generally associated with large offsets of the water content values in the surrounding sediment units. These water content offsets can be both positive and negative. Thrust zones and décollements can be conduits where fluids are transported from surrounding sediment units, or they can be a boundary, where drainage of surrounding sediment units is prevented.

3. The morphology of the subducting plate affects the water content trends and their magnitudes.

4. In sediment composed of unmodified mud, a steepening of the water content gradient occurs across the accretionary prism at Leg 110 (Barbados Ridge), which is consistent with the results of Bray and Karig (1985). The water content gradients at Leg 134 sites are probably more influenced by the stress associated with the subduction of the NDR and the SDC than by the location of the sites in the Vanuatu accretionary prism.

\section{RECOMMENDATIONS}

In order to increase our knowledge of accretionary prisms, it is very useful to study the physical properties of accreted sediment. By comparing physical properties of sediment, factors such as stress history and deformational history can be determined. Water content of the sediment was one of the physical properties studied in this paper. An attempt was made to compare and explain the water content variations which occur at three accretionary prisms. Convergence rates, the morphology of the subducted plate, the location within the prism, and the lithology are some factors which seem to be contributed for variations in water content. However, because of gaps in the data set, it has not been possible to fully explain why the water content differs. Future research is therefore recommended and should entail detailed studies of the consolidation of sediment as well as their sedimentological composition. Consolidation tests of the sediment make it possible to differentiate between normal consolidation, which varies with sediment type, and other consolidation processes (i.e., diagenesis and tectonic loading). Furthermore, from consolidation tests, it is possible to determine the porosity-depth functions, to correct the data for in-situ pore pressure, and to determine the stress history. Sedimentological analysis of the samples used for the physical properties measurements should include grain-size and physico-chemical analyses. This gives us a better mean of comparison between samples of different composition and stress history.

\section{ACKNOWLEDGMENTS}

This research was supported by Swedish Natural Research Council grant G-GU 3447-317 to Ask, and a JOI/NSF (USSAC) grant to Leonard. The statistical analyses were made by Dr. Jan Enger at the Royal Institute of Technology. We acknowledge Dr. Daniel Karig and Bill Rose for reviewing and improving this article. We are also grateful to Dr. Jan Backman at the University of Stockholm for his assistance and to Prof. Ove Stephansson and Dr. Joanne Fernlund for their comments. We dedicate this article to Pam Reid, Bill Meyer, and the participants of Legs 134, 131, and 110, without whom it would not have been possible.

\section{REFERENCES $*$}

Boyce, R.E., 1976. Definitions and laboratory techniques of compressional sound velocity parameters and wet-water content, wet-bulk density, and porosity parameters by gravimetric and gamma ray attenuation techniques. In Schlanger, S.O., Jackson, E.D., et al., Init. Repts. DSDP, 33: Washington (U.S. Govt. Printing Office), 931-958.

Bray, C.J., and Karig, D.E., 1985. Porosity of sediments in accretionary prisms, and some implications for dewatering processes. J. Geophys. Res., 90:768-778.

Carson, B., and Berglund, P.L., 1986. Sediment deformation and dewatering under horizontal compression: experimental results. In Moore, J.C. (Eds.), Structural Fabric in Deep Sea Drilling Project Cores From Forearcs. Mem.-Geol. Soc. Am., 166:135-150.

Chamot-Rooke, N., Renard, V., and Le Pichon, X., 1987. Magnetic anomalies in the Shikoku Basin: a new interpretation. Earth Planet. Sci. Lett., $83: 214-228$.

Chilingarian, G.V., and Rieke, H.H., III, 1974. Compaction of Argillaceous Sediments: New York (Elsevier).

Collot, J.-Y., and Fisher, M.A., 1991. The collision zone between the North d'Entrecasteaux Ridge and the New Hebrides Island Arc. Part 1: Seabeam morphology and shallow structure. J. Geophys. Res., 96:4457-4478.

, 1992. The d'Entrecasteaux Zone-New Hebrides Island Arc collision zone: an overview. In Collot, J.-Y., Greene, H.G., Stokking, L.B., et al., Proc. ODP, Init. Repts., 134: College Station, TX (Ocean Drilling Program), 19-31.

Collot, J.-Y., Greene, H.G., Stokking, L.B., et al., 1992. Proc. ODP, Init. Repts., 134: College Station, TX (Ocean Drilling Program).

Daniel, J., Collot, J.Y., Monzier, M., Pelletier, B., Butscher, J., Deplus, C., Dubois, J., Gérard, M., Maillet, P., Monjaret, M.C., Récy, J., Renard, V., Rigolot, P., and Temakon, S.J., 1986. Subduction et collision le long de l'arc des Nouvelles-Hébrides (Vanuatu): résultats préliminaires de la campagne SEAPSO (Leg 1). C. R. Acad. Sci. Ser. 2, 303:805-810.

Dorel, J., 1981. Seismicity and seismic gap in the Lesser Antilles arc and earthquake hazard in Guadalupe. Geophys. J. R. Astron. Soc., 67:679-695.

Fisher, M.A., Collot, J.-Y., and Smith, G.L., 1986. Possible causes for structural variation where the New Hebrides island arc and the d'Entrecasteaux zone collide. Geology, 14:951-954.

Hedberg, H.D., 1936. The gravitational compaction of clays and shales. Am. J. Sci., 5:241-287.

Kagami, H., Karig, D.E., Coulbourn, W.T., et al., 1986. Init. Repts. DSDP, 87: Washington (U.S. Govt. Printing Office).

Karig, D.E., and Angevine, C.L., 1986. Geologic constraints on subduction rates in the Nankai Trough. In Kagami, H., Karig, D.E., and Coulbourn, W.T., et al., Init. Repts. DSDP, 87: Washington (U.S. Govt. Printing Office), 789-796.

Leonard, J.N., 1991. Physical and geotechnical properties of seafloor sediments from the Vanuatu collision zone in the central New Hebrides island arc, South Pacific Ocean [Ph.D. dissert.]. Texas A\&M Univ., College Station, TX.

Mascle, A., Moore, J.C., et al., 1988. Proc. ODP, Init. Repts., 110: College Station, TX (Ocean Drilling Program).

Molnar, P., and Sykes, L.R., 1969. Tectonics of the Caribbean and Middle America regions from focal mechanisms and seismicity. Geol. Soc. Am. Bull., 80:1639-1684.

Moore, G.F., Karig, D.E., Shipley, T.H., Taira, A., Stoffa, P.L., and Wood, W.T., 1991. Structural framework of the ODP Leg 131 area, Nankai Trough. In Taira, A., Hill, I., Firth, J.V., et al., Proc. ODP, Init. Repts., 131: College Station, TX (Ocean Drilling Program), 15-20.

Moran, K., Brückmann, W., Feeser, V., and Campanella, R.G., 1993. In-situ stress conditions at Nankai Trough, Site 808. In Hill, I.A., Taira, A., Firth, J.V., et al., Proc. ODP, Sci. Results, 131: College Station, TX (Ocean Drilling Program), 283-291.

\footnotetext{
Abbreviations for names of organizations and publications in ODP reference lists follow the style given in Chemical Abstracts Service Source Index (published by American Chemical Society).
} 
Morelock, J., and Bryant, W.R., 1972. Consolidation of marine sediments. In Rezak, R., Henry, V.J. (Eds.), Contributions on the Geological and Geophysical Oceanography of the Gulf of Mexico. Tex. A\&M Oceanogr. Stud., 3:181-202.

Richards, A.F., and Hamilton, E.L., 1967. Investigations of deep-sea sediment cores. III: Consolidation. In Richards, A.F. (Ed.), Marine Geotechnique: Urbana (Univ. of Illinois), 93-117.

Robertson, E.C., 1967. Laboratory consolidation of carbonate sediment. In Richards, A.F. (Ed.), Marine Geotechnique: Urbana (Univ. of Illinois), $118-123$.

Seno, T., 1977. The instantaneous rotation of the Philippine Sea plate relative to the Eurasian plate. Tectonophysics, 42:209-226.

Shipboard Scientific Party, 1988. Synthesis of shipboard results: Leg 110 transect of the northern Barbados Ridge. In Mascle, A., Moore, J.C., et al., Proc. ODP, Init. Repts., 110: College Station, TX (Ocean Drilling Program), 577-591.

1991a. Geological background and objectives. In Taira, A., Hill, I., Firth, J.V., et al., Proc. ODP, Init. Repts., 131: College Station, TX (Ocean Drilling Program), 5-14.

, 1991b. Site 808. In Taira, A., Hill, I., Firth, J.V., et al., Proc. ODP, Init. Repts., 131: College Station, TX (Ocean Drilling Program), 71-272.

, 1992. Site 830. In Collot, J.-Y., Greene, H.G., Stokking, L.B., et al., Proc. ODP, Init. Repts., 134: College Station, TX (Ocean Drilling Program), 261-315.

Stein, S., DeMets, C., Gordon, R.G., Brodholt, J., Argus, D., Engeln, J.F., Lundgren, P., Stein, C., Wiens, D.A., and Woods, D.F., 1988. A test of alternative Carribbean Plate relative motion models. J. Geophys. Res., 93:3041-3050.

Sykes, L.R., McCann, W.R., and Kafka, A.L., 1982. Motion of Caribbean plate during last 7 million years and implications for earlier Cenozoic movements. J. Geophys. Res., 87:10656-10676.

Taira, A., Hill, I., Firth, J.V., et al., 1991. Proc. ODP, Init. Repts., 131: College Station, TX (Ocean Drilling Program).

Taira, A., Tokuyama, H., and Soh, W., 1989. Accretion tectonics and evolution of Japan. In Ben-Avraham, Z. (Ed.), The Evolution of Pacific Ocean Margins: Oxford (Oxford Univ. Press), 100-123.

Terzaghi, R., 1940. Compaction of lime mud as course of secondary structure. J. Sediment. Petrol., 10:78-90.

Trask, P.D., 1932. Origin and Environment of Source Sediments of Petroleum: Houston (Gulf Publishing Co.).

Westbrook, G.K., Smith, M.J., Peacock, J.H., and Poultier, M.J., 1982. Extensive underthrusting of undeformed sediment beneath the accretionary complex of the Lesser Antilles subduction zone. Nature, 300:625-628.

Wright, A., 1984. Sediment distribution and depositional processes operating in the Lesser Antilles Intraoceanic Island Arc, eastern Caribbean. In Biju-Duval, B., Moore, J.C., et al., Init. Repts. DSDP, 78A: Washington (U.S. Govt. Printing Office), 301-324.

Date of initial receipt: 8 May 1992

Date of acceptance: 11 October 1993

Ms 134SR-030 